\title{
What TO DO When You CaN'T Hear THE Whistleblowing: A Proposal to Protect the Public's Health by Providing Whistleblower PROTECTION FOR MEDICAL RESEARCHERS
}

\author{
Jennifer S. Bard*
}

I. INTRODUCTION

II. THE SCOPE OF THE PROBLEM: DANGERS TO THE PUBLIC FROM

MEDICAL RESEARCH AND PRESCRIPTION DRUGS .................................... 7

A. Dangers of Medical Research for Human Subjects.

B. The Importance of Improved Prescription Drug Regulations

Due to Increasing Use in U.S. Culture.

C. Why Regulations are Necessary for Human Subject

Research in the United States.

III. HOW DRUG DEVELOPMENT OCCURS IN THE UNITED STATES .............15

A. The FDA's Role of Goalkeeper........................................... 15

B. The FDA's Rule Making Authority ....................................... 17

C. Existing FDA Protections Insufficient to Protect Research

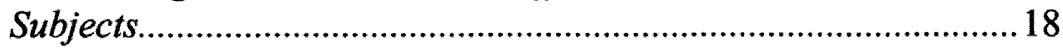

D. FDA Authority to Regulate Clinical Trials.......................... 19

E. How FDA Oversees Clinical Trials ....................................... 21

F. Dangers Arise in all the Four Phases of FDA Regulation....... 22

1. Phase One and Two: Non-Therapeutic Research ...............22

2. Phase Three and Four: Therapeutic Research....................23

3. The Particular Dangers in Stages Three and Four:

Dangers from the Therapeutic Misconception..........................26

IV. MOVEMENT OF CLINICAL TRIALS OVERSEAS ....................................30

A. The Relationship Between Big PHARMA and Academic

\footnotetext{
* Visiting Professor, Drake University Law School; Alvin R. Allison Professor of Law, Texas Tech University School of Law and Director, Health Law Program; Associate Professor (adjunct) Texas Tech University School of Medicine, Department of Psychiatry. This article was three years in the writing and benefitted from the assistance of many highly skilled and talented people. I thank Kathryn Kennon, Cassie Dallas, Brett Gardner, and Texas Tech Law School Research Librarian Sharon Blackburn for their excellent research assistance. Also, Michele Thaetig, for her computer skills, and Kristi Ward, Brie Sherwin, and Craig Klugman for their extremely helpful comments. Research about overseas participants in clinical trials was sponsored through The Law, Policy, and Ethics Core (LPEC), Western Regional Center of Excellence (WRCE) for Biodefense and Emerging Infectious Diseases Research funded by: Public Health Services, Department of Health and Human Services, and I particularly thank Victoria Sutton for including me in this project and for all her help and assistance. This article is dedicated to the memory of Professor Angela Roddy Holder who first introduced me to the compelling legal and ethical issues faced by participants in human subject research. From 1997 to 2001 I was a member of the Whistleblower Unit at the Connecticut Attorney General's Office. The views expressed in this article are completely my own and do not reflect those of the Connecticut Attorney General's Office.
} 
Medical Centers

1. Evidence of Academic Medicine's Financial Entanglement

with Big Pharma: Ghost Writing and Secret Payments to

Medical Academics

B. Post-market Protection: Dangers to Consumers After a

Drug is Approved.

1. Post-market Reporting

2. Features of Current System Which Increase Post-approval

Damages: How Pharmaceutical Company's Practice of

Ghost Writing Affects the Sale and Marketing of Drugs

After Approval.

3. Off-Label Prescribing.

4. Direct-to-Consumer Advertising.

V. WHY IS IT SO DIFFICULT TO GET INSIDE INFORMATION:

WHISTLEBLOWER PROTECTION FOR MEDICAL RESEARCHERS

A. Brief Overview of Whistleblowing: Unknown Risks and

Permanent Harm of Whistleblowing.

B. Whistleblowers' Historical Role in Science and Medicine........51

C. Researchers in Drug Research are also Bound by

Confidentiality Agreements, which Impose Penalties for

Violation of the Company's Trade Secrets

VI. WHY EXISTING WHISTLEBLOWER PROTECTION LAWS DON'T WORK 54

A. Lack of Constitutional Protection...............................................56

1. Medical Researchers Are Not Protected by the First

Amendment?.

a. Federal whistleblower law provides little protection

for federal employees and none for private employees

$b$. Characterizing hiding information about a drug as a

false claim against the government

B. Neither Qui Tam Statutes nor Bounty Programs are not a

Substitute for Whistleblower Protection.

1. Qui Tam Actions

2. Federal Whistleblower Laws

C. State Whistleblower Laws Do Not Protect Most Medical

Researchers

VII. CONCLUSIONS

\section{INTRODUCTION}

Both the safety of human subjects participating in medical research ${ }^{1}$

1. The National Institutes of Health ("NIH") defines "clinical research" as "research that either directly involves a particular person or group of people or uses materials from 
and the consumers of the research's products ${ }^{2}$ are of vital importance to the public's health. Unfortunately, most prescription drugs are developed behind closed doors by private manufacturing companies. Before a drug can be sold in the United States, the Food and Drug Administration (FDA) has the authority pursuant to the provisions of the Food and Drug Administration Amendments Act of 2007 (FDAA) to ensure all drugs sold in the United States are both safe and effective. ${ }^{3}$

Once approved by the FDA, however, it is these same private companies which are responsible for monitoring reports of emerging harm once the drug is on the market. This structure of private development and private post-market oversight means that the only people with access to new information are those who work inside the company itself. ${ }^{4}$ While some risks

humans, such as their behavior or samples of their tissue, that can be linked to a particular living person" and further explains that "Clinical research is medical research involving people." Clinical Research \& Clinical Trials, NAT'L INSTITUTES OF HEALTH, http://www.nichd.nih.gov/health/clinicalresearch/ (last updated July 23, 2009); Patient Recruitment at the NIH Clinical Center, NAT'L INSTITUTES OF HEALTH, http://www.cc.nih.gov/ recruit/ (last updated Nov. 22, 2010). For purposes of this paper, I adopt the Federal definition of research as "a systematic investigation, including research development, testing and evaluation, designed to develop or contribute to generalizable knowledge." 45 C.F.R. $\S$ 46.102(d) (2011).

2. While this article uses the general term "drug," the risks to the public from medical devices, such as pacemakers, biologics, such as blood clotting agents, and vaccines, are equally serious, and rather than highlight the differences, this article will emphasize the similarity of risk. Proposals to protect individuals with knowledge of dangerous procedures used to develop a drug which would be a risk to public health apply equally strongly to any medical product requiring approval of the Food and Drug Administration pursuant to its general authorizing statute, the Federal Food, Drug, and Cosmetic Act. See 21 U.S.C. § 393 (2011).

3. The FDA has not always had this authority. Until 1962, drugs were automatically approved for sale if the FDA did not act within sixty days. Many drugs currently on the market were submitted under that schema and have never been approved by the FDA. See Caitlin E. Fleming, Overdosed and Contaminated: A Critical Examination of the FDA and Drug Industry's Role in Drug Safety in the Context of the Heparin Catastrophe, 13 QUINNIPIAC HEALTH L.J. 117, 150 (2009) (reviewing the history of how drugs like Heparin were approved without active FDA approval and describing the FDA's current abilities to oversee drugs after hitting the market). See also Renewed Legislation Improves Safety of FDA-Regulated Products, FDA, http://www.fda.gov/ForConsumers/ConsumerUpdates/ ucm061229.htm (last updated Jan. 18, 2012) (explaining that the Food and Drug Administration Amendments Act of 2007 provided the FDA with funds to oversee clinical trials and to review television marketing aimed at consumers); Significant Amendments to the FD\&C Act, FDA, http://www.fda.gov/RegulatoryInformation/Legislation/FederalFoodDrugandCosmetic ActFDCAct/SignificantAmendmentstotheFDCAct/default.htm (last updated Apr. 29, 2011); Inspections, Compliance, Enforcement, and Criminal Investigations, FDA, http://www.fda.gov/ICECI/ComplianceManuals/CompliancePolicyGuidanceManual/ucm074 382.htm (last updated Sept. 16, 2011) (describing the FDA's 1962 grandfather clause policy exempting a drug from the effectiveness requirement "if its composition and labeling has not changed since 1962 and if, on the day before the 1962 Amendments became effective, it was (a) used or sold commercially in the United States, (b) not a new drug as defined by the FD\&C Act at that time, and (c) not covered by an effective application").

4. Eliot Spitzer, Regulators and Risk-Takers: Didn't Big Pharma or the FDA Learn Anything from the Gulf Oil Spill or the Wall Street Meltdown?, SLATE (July 14, 2010), http://www.slate.com/id/2260470/. While FDA regulation requires drug companies to halt clinical trials if there is evidence of undue risk, it must rely on the company's own judgment 
cannot be anticipated, others may be suppressed because they are against the manufacturer's financial interest.

Sadly, many recent examples point to such deliberate omissions. For example, the pharmaceutical company GlaxoSmithKline withheld negative information suggesting that Avandia, a popular drug used by diabetics, increased the rate of heart attacks. ${ }^{5}$ Concerned about the avoidable deaths, Senator Max Baucus said that "Information is the most important tool the FDA has to protect American consumers, and the documents we uncovered in our investigation will help arm the FDA with the best information possible as it evaluates Avandia's safety." Similar allegations have been made against Merck \& Company, manufacturer of Vioxx. Evidence disclosed during a series of lawsuits against Vioxx exposed information demonstrating an increased rate of heart attacks, first among research subjects taking the drug and then patients. ${ }^{7}$ Drugs that were intended to keep patients healthy instead resulted in thousands of patient deaths.

It is the fragmented way research and drug development is structured in the United States which makes it so hard to protect the public. U.S. law divides human subjects' safety oversight into two separate jurisdictions: first, research funded by agencies of the Federal Government ${ }^{8}$ and second, drug trials paid for by pharmaceutical companies. ${ }^{9}$ This article provides an overview of the current system with the goal of showing where these gaps are, why it is important to close them, and how difficult a task this will be. Without understanding why and how the current uncoordinated, ramshackle, and weak laws specifically fail to protect the public's health it is impossible to craft or implement effective change. This article, however, is not merely descriptive; it is also normative. It proceeds from the position that the federal government should protect the public against dangers from prescription drugs and moreover that employees who work for drug manufac-

in either stopping the trial itself or disclosing the interim results to the FDA.

5. Gardiner Harris, Diabetes Drug Maker Hid Test Data, Files Indicate, N.Y. TIMES (July 13, 2010), http://www.nytimes.com/2010/07/13/health/policy/13avandia.html.

6. Press Release, United States Senate Committee on Finance, Baucus, Grassley Find Company Failed to Promptly Alert FDA about Drug Risks: Finance Leaders Send Findings to FDA Regarding Safety of Diabetes Drug Avandia (July 13, 2010), http://finance. senate.gov/newsroom/chairman/release/?id=bcf5aef6-9bc5-45ca-9cab-aadf5df135fa.

7. The manufacturer of Vioxx, Merck \& Co., Inc., has neither admitted nor received official sanctions for deliberately concealing information. The allegations are that it was aware of a pattern of adverse events which it decided did not present a danger and therefore did not warrant disclosure to the FDA. However, had there been a procedure for sending individual concerns directly to the FDA, the FDA might well have heard about the results earlier and made its own conclusions about the significance of the data. See generally RENA Steinzor \& Margaret Clune, The Hidden Lesson of the Vioxx Fiasco: Reviving a Hollow FDA (2005), available at http://www.progressivereform.org/articles/Vioxx 514.pdf (recounting the Vioxx story and arguing that the FDA has insufficient resources to conduct independent review of drug safety issues which emerge after marketing).

8. Gardiner Harris, The Safety Gap, N.Y. TIMES (Oct. 31, 2008), http://www.nytimes.com/2008/11/02/magazine/02fda-t.html.

9. About PhRMA, PHARMACEUTICAL RES. \& MFRS. OF AM., http://www.phrma.org/ about/about-phrma (last visited Dec. 30, 2011). 
turing and development companies should receive adequate protection for bringing information about these dangers to a regulatory agency with the power to address them. Since the Food and Drug Administration (FDA) controls every aspect of the development, production, and marketing of a drug to be sold in the United States it is the obvious choice for this role. ${ }^{10}$

Because the FDA already has umbrella jurisdiction over drug development, production, and marketing, the reform proposals made in this article can be implemented directly through the agency's own rule making authority and once done will extend protection to every participant in a drug trial and every consumer who later is prescribed that drug. As a result, those who voluntarily participate in drug trials are often exposed to dangers far beyond what they agreed to. In both cases, participants or insiders with the most knowledge are prevented from coming forward because of very real fears of retaliation and loss, not of their jobs, but of their careers. ${ }^{11}$

Improving information flow by developing a safe and effective whistleblower procedure will not be an easy task. Drug trials are complex and often occur at multiple test sites, both public and private, in many different states in the United States, as well as overseas. ${ }^{12}$ As a result, the pool of potential people with relevant knowledge is very large and transcends employment status, job title, or physical location. On the other hand, the target audience to receive complaints is very specific: the FDA. This means that the protection available must be sufficient to encourage disclosure by highlevel scientists, doctors, or pharmaceutical company executives for whom disclosure would be career ending. ${ }^{13}$ Finally, to be effective, a solution

10. It is a crime to distribute any drug in the United States without the FDA's approval. See 21 U.S.C. $\$ 331$ (a) (2010) ("The introduction or delivery for introduction into interstate commerce of any food, drug, device, tobacco product, or cosmetic that is adulterated or misbranded [is prohibited].").

11. Most employees in the United States are "employees at will" and therefore can be fired for any reason. Federal employees have slightly more protection since they can be fired only for "cause." See 5 U.S.C. $\$ \S 7501-7543$ (2011) (providing a Merit Systems Protection Board for federal employees). Members of a union also have protection against being fired without cause, but only $11.8 \%$ of American workers are members of unions. See Economic News Release, U.S. Dep't of Labor, Union Members Summary (Jan. 27, 2012), available at http:/www.bls.gov/news.release/union2.nr0.htm ("In 2011, the union membership rate - the percent of wage and salary workers who were members of a union-was 11.8 percent, essentially unchanged from 11.9 percent in $2010 \ldots$. The number of wage and salary workers belonging to unions, at 14.8 million, also showed little movement over the year.").

12. Search for Clinical Trials, ClinICALTRIALS.GOv, http://clinicaltrials.gov/ (last visited Dec. 30, 2011).

13. Whether or not a whistleblower is an employee, retaliation is a very real fear of individuals who criticize the pharmaceutical industry. A recent class action lawsuit in Australia revealed corporate documents outlining a plan to discredit physicians who were criticizing Vioxx. A reporter for a consumer blog who reported on the trial said, "court evidence show[ed] company employees drew up a 'hit list' of doctors, researchers, and academics who, it . . . felt, had to be 'neutralized' or discredited from criticizing the drug." The reporter went on to quote an email by a Merck employee that stated, "we may need to seek them out 
must also recognize both the social science literature, which describes how whistleblowers are encouraged to come forward, and the advances in technology, which can make it possible to disclose information with less risk of retaliation. ${ }^{14}$

Traditional whistleblower protection statutes are usually quite specific and often will only protect disclosures directly related to violations of a specific statute. ${ }^{15}$ Without existing laws identifying prohibited behaviors, it is very difficult to extend protection to potential whistleblowers who may be located anywhere in the world and who may be independent contractors or be employed by either public or private entities.

The FDA cannot, as it is currently structured, take on the task of monitoring and responding to a broadly conceived whistleblower program. Importantly, this article does not criticize the FDA's good faith attempt at overseeing the activity of drug companies, although others do. Commenting on the approval of the weight loss drug Orliset, Dr. Sidney Wolf, member of the consumer advocacy group Public Citizen and frequent critic of the FDA, described the Agency's decision as "the height of recklessness and shows a profound lack of concern for the public's health."16 The reason this article does not address these criticisms is that if the FDA is acting in bad faith, then any attempt at reform is fruitless. Assuming, however, that the FDA is committed to fulfilling its statutorily assigned function of protecting the public, then monitoring the suggested information is a problem that can be solved simply by money.

Part II of this article reviews the dangers to the public from participating in clinical drug trials research and from taking prescription drugs.

Part III provides a short history of how clinical drug trials came to be regulated and current FDA regulations of research and oversight of clinical trials.

Part IV considers the actions of pharmaceutical companies after the drug trials are over and outlines the dangers to the public from companies' marketing of new drugs. It also explains the current trend toward conduct-

and destroy them where they live." Melanie Segala, How Big Pharma Threatens Its Critics, DR. JOHNNY BOWDEN's BLOG (June 6, 2009), http://www.jonnybowden.com/labels/ Vioxx.html.

14. Darcy S. O'Neil, Technology and the Whistleblower, ARTICLEGEEK, http://www.articlegeek.com/business/ethics_articles/whistleblower_technology.htm (last visited Dec. 31, 2011).

15. See Richard Moberly, Protecting Whistleblowers by Contract, 79 U. Colo. L. REV. 975, 982 (2008) ("Although federal anti-retaliation protections collectively cover a broad range of industries, each of the individual statutes applies only to a specific type of employee who blows the whistle about a specific topic. This statutory framework results in a network of narrow protections that evolved on an ad hoc basis to support specific statutory schemes.").

16. Press Release, Public Citizen, FDA APProval of Over-THE-Counter ORLISTAT IS RECKLESS (FEB. 7, 2007), available at http://www.citizen.org/hot_issues/ print_issue.cfm?ID=1539. See generally Drugs, DEVICES AND SUPPLEMENTS, Public Citizen, HTTP://WWW.CITIZEN.ORG/PAGE.ASPX?PID=1249 (LAST VISITED NOV. 10, 2011). 
ing clinical trials overseas, as well as the trend toward even closer relationships between pharmaceutical companies and the doctors and research scientists employed by university affiliated academic medical centers. Part IV also elucidates post-market dangers to the consumer and outlines the current system of laws protecting medical researchers who want to bring the information forward.

Part V identifies the deficiencies of existing federal law to protect insiders with knowledge. This article identifies the paramount features any proposed regulation must include to provide adequate incentives for disclosure. Finally, the article addresses both substantive and normative issues raised as a result of this protection. ${ }^{17}$ This article is the first of a planned two-part series. It identifies the dangers to the public during drug testing and the marketing of a new drug and reviews the existing options for protecting those with knowledge. In a subsequent article, the author plans to offer a series of proposals which would offer further protection. All whistleblower laws are premised on the idea that protection from retaliation will increase the likelihood the public will hear of potential dangers before being exposed to them. ${ }^{18}$ This article demonstrates why protection needs to come from the federal government and why these regulations are well within existing federal powers.

\section{THE SCOPE OF THE PROBLEM: DANGERS TO THE PUBLIC FROM MEDICAL RESEARCH AND PRESCRIPTION DRUGS}

\section{A. Dangers of Medical Research for Human Subjects}

Consumer watchdog groups, ${ }^{19}$ doctors, ${ }^{20}$ Congressmen, ${ }^{21}$ bioethi-

17. See generally Courtney J. Anderson DaCosta, Note, Stitching Together the Patchwork: Burlington Northern's Lessons for State Whistleblower Law, 96 GEO. L.J. 951 (2008); Robert Johnson, Comment, Whistling While You Work: Expanding Whistleblower Laws To Include Non-Workplace-Related Retaliation After Burlington Northern v. White, 42 U. Rich. L. REV. 1337 (2008); Paul M. Secunda, Whither the Pickering Rights of Federal Employees?, 79 U. CoLo. L. REV. 1101 (2008).

18. Stewart J. Schwab, Wrongful Discharge Law and the Search for Third-Party Effects, 74 TEX. L. REV. 1943, 1966-68 (1996) (reviewing the extent to which whistleblowers fear retaliation and therefore require this protection from statutes).

19. See, e.g., News Release, Accenture, Recent Drug Recalls Leave Physicians and Consumers Concerned About Prescription Drug Safety (July 27, 2005), http://newsroom.accenture.com/article_display.cfm?article_id=4239\#rel (surveying "more than 100 U.S. physicians and 500 U.S. consumers" and finding that "two-thirds (67 percent) of doctors and one-third ( 32 percent) of consumers have become more concerned about the safety of prescription medications since the recent removal from the market of popular pain relievers").

20. In a comment attached to an article in the New York Times about GlaxoSmithKline's hiding of safety information about their drug Avandia Dr. Rick Lippin of Southampton, Penn., wrote,

As a physician I am really very weary of reading these many stories in 
cists, ${ }^{22}$ legal academics, ${ }^{23}$ and courts ${ }^{24}$ have all noted with concern the risks the public faces both from participating in medical research and in taking the drugs which emerge from the process. In order to adequately appreciate a proposal to decrease the dangers from prescription drugs, it is necessary to understand the scope of the problem both in terms of existing dangers and in terms of the complexities of the existing regulatory protections.

Every prescription drug sold in the United States reaches the market through testing on brave and often altruistic individuals who take the risks of testing new and untried products. ${ }^{25}$ These volunteers are part of a multifaceted and complex system in which ideas and discoveries in laboratories are transformed into the drugs, devices, and vaccines prescribed to the general market. ${ }^{26}$. Regardless of how much promise a drug shows in laboratory or even animal testing, it must eventually be tried on the human patients for whom it is intended. ${ }^{27}$ This is sometimes a dangerous process that can lead to injury and death. ${ }^{28}$

recent years. It is obvious that fines, lawsuits and bad publicity are not working. The only method of stopping these behaviors is to charge the most egregious CEOs of Big PhRMA [sic] with crimes and to sentence them to jail.

See Harris, supra note 5, at cmt. 121.

21. Asked for his opinion in the same article about allegations that GlaxoSmithKline had hidden safety information about Avandia, Senator Max Baucus said, "When drug companies withhold data regarding safety concerns about their medicines, they put patients at risk." Harris, supra note 5.

22. Susan Gilbert, Industry-Funded Drug Trials: Devils in the Details, THE HASTINGS CENTER: BIOETHICS FORUM (Aug. 10, 2010), http://www.thehastingscenter.org/ Bioethicsforum/Post.aspx?id=4823\&blogid $=140$.

23. Rebecca Dresser, Time for New Rules on Human Subjects Research?, 28 HASTINGS CENTER REPORT 23, 23-24 (1998). 2001)

24. See, e.g., Grimes v. Kennedy Krieger Inst., Inc., 782 A.2d 807, 815-17 (Md.

25. See What is the Approval Process for a New Prescription Drug?, FDA, http://www.fda.gov/AboutFDA/Transparency/Basics/ucm194949.htm (last visited Dec. 31, 2011) ("Drug companies seeking FDA approval to sell a new prescription drug in the United States must test it ... in humans to see if the drug is safe and effective when used to treat or diagnose a disease.").

26. Id.

27. Detailing the need for further protection for the first humans to test a drug developed through laboratory and then animal testing, Rebecca Dresser reminds us that "[w]e should not lose sight of an uncomfortable reality: [these] trials expose healthy people with limited economic opportunities and ill people with limited health options to harm for the benefit of others." Rebecca Dresser, First-in-Human Trial Participants: Not a Vulnerable Population, but Vulnerable Nonetheless, 37 J.L. MED. \& ETHICs 38, 47 (2009).

28. See Robert Steinbrook, The Gelsinger Case, in THE OXFORD TEXTBOOK OF CliniCAL RESEARCH ETHICS 110 (Ezekiel Emanuel et al. eds., 2008) for an account of one of the most defining cases involving the death of a teenage research subject. The public is well aware that neither pharmaceutical companies nor academic medical centers have done all they should to protect human subjects. Almost $25 \%$ of people surveyed by the Harvard School of Public Health believed that most pharmaceutical companies acted unethically when testing new drugs on people. USA TODAY, KaISER FAMILY FOUND. \& HARVARD SCH. of Pub. Health, The Public on Prescription Drugs and Pharmaceutical Companies 22

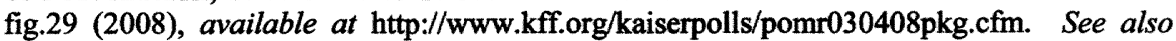


Compared to the information available on sickness and death caused by drugs already on the market, the information on harm from drugs while they are being researched and developed is quite scanty. ${ }^{29}$ There is no central registry of harm suffered by participants in drug trials. ${ }^{30}$ Experts estimate that between ten and nineteen million Americans participate in the testing and development of prescription drugs. ${ }^{31}$ Not all of these experiments end well. There may well be up to ten thousand research-related deaths occurring per year, which is proportionate to normal death rates among a population between ten and nineteen million research subjects. ${ }^{32}$ Direct access to research-related adverse effects is often unavailable since there is not direct access to such information because, whether drugs are developed by private companies or in academic medical centers, those with knowledge face not just dismissal, but lawsuits for violations of strict confidentiality and non-disclosure agreements. ${ }^{33}$

The history of medical research in the United States is marked by frightening incidents in which participants in drug trials were killed or seriously injured despite elaborate regulations intended to protect them. Medi-

Anna C. Mastroianni, Sustaining Public Trust: Falling Short in the Protection of Human Research Participants, HASTINGS CTR. REP. (2008) (citing the USA Today statistic in a call for greater protection of human subjects and stating, "To create accountability, the public needs to be assured that processes are in place to protect research participants.").

29. See Mark Greener, First Do No Harm: Improving Drug Safety Through Legislation and Independent Research, 9 EMBO Reports 221 (2008), available at http://www.ncbi.nlm.nih.gov/pmc/articles/PMC2267386/pdf/embor200817.pdf.

30. Sarah Rubenstein, When Drug Trials Go Wrong, Patients Have Little Recourse, WALL ST. J. (Jan. 31, 2008), http://online.wsj.com/article/SB120173515260330205.html (showing compensation plans for harmed participants vary by institution and despite calls to standardize compensation programs, adoption is minimal).

31. In 2001, Dr. Adil E. Shamoo, a highly respected expert in human subject research, published the results of a study he conducted to estimate the number of humans participating in medical research and the number suffering injury or death as a result. Noting that the report of only eight deaths in federally funded research studies over ten years was "absurdly low," he estimated the actual number of injuries every year in the "tens of thousands" and the "deaths in the thousands." He found it necessary to estimate these figures because the way human subject research is organized in the United States precludes any access to comprehensive data. He analyzed available information from an array of government sources including tracking studies funded by the National Institutes of Health and those funded by pharmaceutical companies and non-governmental sources which were under the jurisdiction of the Food and Drug Administration because they were intended to support an application for an Investigational New Drug ("IND"). Dr. Shamoo's failure to identify any reliable source of either the number of people participating in human subject research or their rates of injury or death provides a helpful overview of how human subject research and new drug development is regulated in the United States. See Adil E. Shamoo, Adverse Events Reporting: The Tip of an Iceberg, 8 ACCOUNTABILITY IN RES. 197 (2001).

32. Shamoo, supra note 31 , at 198.

33. See Stewart Lyman, Pharma-Academic Alliances: What the Numbers Don't Tell You, Xconomy (MAY 10, 2011), http://www.xconomy.com/seattle/2011/05/10/pharmaacademic-alliances-what-the-numbers-dont-tell-you/ (last visited Mar. 17, 2012); see also The Corrupt Alliance of the Psychiatric-Pharmaceutical Industry, Citizens Commission on Human Rights International, http://www.cchrint.org/cchr-issues/the-corrupt-alliance-of-thepsychiatric-pharmaceutical-industry/ (last visited Mar. 17, 2012). 
cal research, one of the most respected endeavors of modern society, ${ }^{34}$ has turned out to be an enterprise full of risk and menace. At the same time, prescription drug consumption in the United States has increased every year. ${ }^{35}$ Today, any clinical trial conducted with intent of providing support for a New Drug Application (NDA) must comply with the human subject research protections of the "Common Rule" which applies to all research both funded by and overseen by any Federal Agency. ${ }^{36}$

The transition from limited and closely monitored trials involving a small number of patients to the actual marketing of the drug to the general public has been described as "stage 5" testing because it is often only then that serious side-effects and counter-indications become known. ${ }^{37}$

A series of front-page stories in the New York Times during the summer of 2010 tells the story of how one of the largest pharmaceutical companies went to extraordinary efforts to hide the dangers of Avandia, a drug that increased the risk of heart attack for the diabetic patients to whom it was prescribed. ${ }^{38}$ Describing the studies offered by the company in support of its product as "totally incorrect and deceptive," 39 members of the FDA panel which was convened to review the charges criticized the company's failure to protect the public from risks of which it was well aware.

These allegations echoed those made in a lawsuit brought in 2004 by the State of New York against GlaxoSmithKline for allegedly concealing known dangers of suicide by children and adolescents using its prescription

34. Depending on the question asked, the public's views of science, technology, and medicine can differ, but in general, efforts viewed to improve health are viewed with favor by the American public. See Dov Greenbaum, Research Fraud: Methods for Dealing with an Issue that Negatively Impacts Society's View of Science, 10 COLUM. SCI. \& TECH. L. REV. 61, 65 n.10 (2009) ("Science studies what is; technology creates what never was." (quoting D. Allan Bromley, Sheffield Lecture at Yale University: Science, Technology, and Politics (Mar. 22, 2001))).

35. QIUPING Gu et al., Prescription Drug Use Continues to Increase: U.S. PRESCRIPTION DRUG DATA FOR 2007-2008 1 (2010) (showing trends in prescription drug use in the United States over the years 1999-2008), available at http://www.cdc.gov/nchs/data/ databriefs/db42.pdf. See also Wayne Kondro \& Barbara Sibbald, Drug Company Experts Advised Staff to Withhold Data About SSRI Use in Children, 170 CANADIAN MED. Ass'N J. 783, 783 (2004), available at http://www.cmaj.ca/cgi/content/full/170/5/783.

36. Federal Policy for the Protection of Human Subjects ('Common Rule'), U.S. DEPT. OF HEALTH \& HUMAN SERVS., http://www.hhs.gov/ohrp/humansubjects/commonrule/ index.html (last visited Feb. 3, 2012); 45 C.F.R. § 46.101(a) (2012) ("[T] his policy applies to all research involving human subjects conducted, supported or otherwise subject to regulation by any federal department or agency which takes appropriate administrative action to make the policy applicable to such research.").

37. Glossary: Clinical Trials Terminology, ApPLIED CliniCal Trials, Dec. 2002, at 30, available at http://staff.aub.edu.lb/ webmedic/Appendix14.pdf ("Postmarketing surveillance is sometimes referred to as Phase 5.").

38. Harris, supra note 5 .

39. Gardiner Harris, F.D.A. Panel Votes to Restrict Avandia, N.Y. Times (July 14, 2010), http://www.nytimes.com/2010/07/15/health/policy/15diabetes.html (quoting Dr. William Knowler's description of another GlaxoSmithKline study). 
anti-depression drug Paxil. ${ }^{40}$

While the identities of most research subjects are known only to their families, there are several very famous examples to the contrary. Perhaps best known is eighteen-year-old Jesse Gelsinger who died while participating in a genetic therapy study that was of no medical value to him but of considerable value to his physician who had created a company to market the therapy to others. ${ }^{41}$ Another youth, Ellen Roche, a Johns Hopkins lab technician, volunteered to test an anti-asthma medicine and died a month after her lungs were damaged fatally because the researcher had induced lung spasms using a drug that had never been approved for use in humans. ${ }^{42}$ In the face of these tragedies, it is reasonable for Americans to ask why the seemingly vast array of laws and regulations intended to ensure the safety of both research subjects and those who eventually use the products tested could have failed so dramatically and what steps can be taken to prevent future harm.

\section{B. The Importance of Improved Prescription Drug Regulations Due to In- creasing Use in U.S. Culture}

Prescription drug use has permeated American society. In the news

40. Complaint, New York ex rel. Spitzer v. GlaxoSmithKline PLC, (N.Y. 2004), available at http://fll.findlaw.com/news.findlaw.com/cnn/docs $/$ glaxo/nyagglaxo60204cmp. pdf (last visited Feb. 4, 2012).

41. See generally Robin Wilson, The Death of Jesse Gelsinger: New Evidence of the Influence of Money and Prestige in Human Research, 36 AM. J. L. \& MED. 295 (2010). Although ethicists and researchers at the University of Pennsylvania defended the integrity of the experiment, the university reached a non-public settlement with the family and the lead investigator was banned for five years from doing human subject research again. See Cheryl G. Stolberg, Institute Restricted After Gene Therapy Death, N.Y. TIMES (May 25, 2000), http://www.nytimes.com/2000/05/25/us/institute-restricted-after-gene-therapy-

death.html?ref $=$ jesse_gelsinger. In an interview with Scientific American about an article the FDA required he write about lessons learned, the reporter quoted him as stating that he "would not do the study again" and then paraphrased his explanation: "In the 1990s scientists such as himself, he explains, were too caught up in the promise of gene therapy to realize that they did not know enough about it to warrant human testing. We were drawn into the simplicity of the concept. You just put the gene in." He further advised future researchers to avoid conducting research in which they had a conflict of interest. Melinda Wenner, Tribulations of a Trial: Lessons Learned by the Scientist Behind the First Gene Therapy Death, ScI. AM., Sept. 2009, at 14-15.

42. For an overview of recent cases in which research subjects were harmed, see generally Marshall S. Shapo, EXPERIMENTING WITH THE Consumer: The Mass Testing of RISKY PRODUCTS ON THE AMERICAN PUBliC 18-29 (2009). The risks are especially high in tests for new psychiatric medications because the FDA requires that their effectiveness be compared against no treatment at all. Thus, patients with documented psychiatric conditions must be taken off all medication for a period long enough for their old medicine to "washout" of their body so that the effects of the experimental drug can be measured accurately. See Peter R. Breggin \& Ginger Ross Breggin, Talking Back to Prozac: What Doctors Aren't Telling You About Today's Most Controversial Drug 84, 224 (1994). 
doldrums of July 2010, sixty-nine percent of the American public, including President Barack Obama, ${ }^{43}$ knew Lindsey Lohan was spending some time in jail. ${ }^{44} \mathrm{~A}$ feature of many of these stories was the number of powerful prescription drugs she took on a daily basis. ${ }^{45}$ This picture of a young woman with no life-threatening disease taking six different powerful prescription drugs is, unfortunately, an accurate reflection of daily life in the United States at the turn of the twenty-first century. We have become a nation of drug-takers. ${ }^{46}$ One of the reasons for this is the increased use of prescription drugs by increasingly broad segments of the population. Fiftynine percent of all Americans, and eighty-six percent of all seniors, take a prescription drug ${ }^{47}$ every day. ${ }^{48}$ There are many explanations for the increasing number of injuries suffered by those taking prescription drugs as

43. Interviewed by the hosts of the $\mathrm{ABC}$ talk show "The View" on July 29, 2010, President Obama responded to a series of questions about his knowledge of popular culture, stating that "he knew Lindsay Lohan was in jail." Jessica Derschowitz,"The View": Obama Talks About His iPod, Lindsay Lohan and His Daughters, CBS News (July 29, 2010), http://www.cbsnews.com/8301-31749_162-20012103-10391698.html.

44. This figure is according to the Pew Research Center for People and the Press, which reports that of Americans polled between July 8 and 11, 2010, twenty-seven percent had heard "a lot" about Lindsay Lohan being sentenced to jail and forty-two percent had heard "a little." Press Release, Pew Res. Ctr., Modest Decline in Oil Leak Interest, Sharp Decline in Coverage (July 14, 2010), available at http://www.people-press.org/files/legacypdf/634.pdf.

45. According to MTV news,

Lohan is cleared to take the antidepressants Zoloft and Trazodone; Adderall, a stimulant used to control ADHD; the acid-reflux medicine Nexium; and the very powerful painkiller Dilaudid, whose effects have been compared to heroin and which she was originally prescribed after dental surgery several months ago. Lohan is subject to random drug and alcohol testing, but because those drugs have been court-approved, positive tests for them are not considered violations.

See Gil Kaufman, Why is Lindsay Lohan on so Many Medications? 'It's Too Complicated a Picture to Add Medications into the Mix so Soon,' One Doctor Tells MTV News, MTV NEws (July 8, 2010), http://www.mtv. com/news/articles/1643256/why-lindsay-lohan-on-so-manymedications.jhtml. For a copy of the probation report, see Probation Officer's Report, California v. Lindsay Dee Lohan, No. 7BV01538-01 (Cal. Sup. Ct. July 6, 2010), available at http://tmz.vo.llnwd.net/o28/newsdesk/tmz_documents/0721_lohan.pdf.

46. The age-adjusted percentage of the population using at least one prescription drug during the previous month increased from thirty-nine percent for 1988-1994 to forty-seven percent for 2005-2008. During the same periods, the percentage taking three or more prescription drugs increased from twelve percent to twenty-one percent. U.S. DEP'T OF HEALTH and Human Servs.: Nat'L CTR. For Health Statistics, Health, United STATES, 2010: WITH SPECIAL FEATURE ON DEATH AND DYING 318 (2011), available at http://www.cdc.gov/ nchs/data/hus/hus10.pdf.

47. See Study Shows More Americans Taking Prescription Drugs, U.S.A. ToDAY (May 14, 2008), http://www.usatoday.com/news/health/2008-05-14-medication-nation N.htm (stating that "more than half of all insured Americans are taking prescription medicines regularly for chronic health problems").

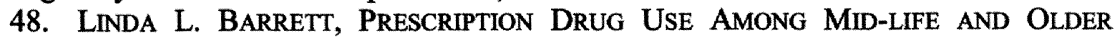
AMERICANS 5 (2005), available at http://assets.aarp.org/rgcenter/health/rx_midlife_plus.pdf (stating that three-quarters of Americans age fifty or older say they currently take prescription drugs on a regular basis). 
directed by their physicians. The CDC attributes the phenomena to the development of new categories of drugs to treat chronic conditions such as high cholesterol and diabetes. ${ }^{49}$ Others point to increased advertising by drug companies including direct-to-consumer advertising in magazines and on television. ${ }^{50}$

\section{Why Regulations are Necessary for Human Subject Research in the United States}

The genesis of regulation of all research involving human subjects in the United States is traced traditionally to the horrors Nazi doctors and scientists inflicted on concentration camp prisoners, as revealed during the Nuremberg war crimes trial. ${ }^{51}$ The core principle of the Nuremberg doctrine, later incorporated into an international treaty called "The Helsinki Accord," was the mandate that all research conducted with human subjects must be done with a subject's informed consent. ${ }^{52}$ The Helsinki Accord has become the foundation of whatever international understanding exists on the boundaries for conducting ethical human subject research. ${ }^{53}$

Because the United States' research community did not see a connection between the research it was doing and the activities of the Nazis, it took over thirty years for the principles developed in Helsinki and Nuremberg to become U.S. law. ${ }^{54}$ As Professor Jay Katz observed in explaining the de-

49. See U.S. Dep't of Health and Human Servis.: Nat'l Ctr. for Health Statistics, Health, United States, 2009: With Special Feature on Medical TECHNOLOGY 94 (2010), available at http:/www.cdc.gov/nchs/data/hus/hus09.pdf ("The use of statin drugs increased almost 10-fold from 1988-1994 to 2003-2006; during the same time period, the use of antidiabetic drugs increased by $50 \%$.").

50. For a history of how pharmaceutical companies came to be allowed to advertise directly to consumers, see Francis B. Palumbo \& C. Daniel Mullins, The Development of Direct-to-Consumer Prescription Drug Advertising Regulation, 57 FOOD \& DRUG L.J. 423 (2002).

51. There are many overviews of this period in history. The original transcripts of the trials can be found at Trials of War Criminals Before the Nuernberg Military Tribunals Under Control Council Law No. 10: October 1946-April 1949, LiBR. ConG., http://www.loc.gov/rr/frd/MilitaryLaw/NTs_war-criminals.html (last updated July 16, 2010). See generally Gail H. Javitt, Old Legacies and New Paradigms: Confusing "Research" and "Treatment" and Its Consequences in Responding to Emergent Health Threats, 8 J. HEALTH CARE L. \& PL'Y 38, 44-49 (2005) (providing a history of the Nuremberg Doctors Trials' role in developing the Nuremberg Code). See also Alan T. Lefor, Scientific Misconduct and Unethical Human Experimentation: Historic Parallels and Moral Implications, 21 NUTRITION 878 (2005).

52. Samantha Evans, The Globalization of Drug Testing: Enforcing Informed Consent Through the Alien Tort Claims Act, 19 TEMP. INT'L \& COMP. L.J. 477, 487 (2005).

53. Id. (conceding that "there is currently no controlling legislative or executive act to establish that informed consent in human subject experimental research is a 'law of nations," but arguing that it has gained the status of "binding customary international law" by considering the Helsinki Doctrine together with succeeding, but separate, guidelines and declarations).

54. Carla M. Stalcup, Reviewing The Review Boards: Why Institutional Review Board 
lay, "It was a good code for barbarians, but an unnecessary code for ordinary physicians." $" 55$ Instead, the activities exposed at Nuremberg were seen as the result of extraordinary circumstances that were outside the usual conduct of scientific research.

The first steps towards legal regulation of research involving living humans came in the wake of Congressional hearings, which considered Henry Beecher's 1973 report detailing the history of human subject research abuse, not by foreign monsters, but rather by highly respected doctors and scientists within the United States. ${ }^{56}$ This was followed the next year by the revelations of the syphilis trials conducted by the Public Health Service on African-American sharecroppers in Tuskegee, Alabama ("The Tuskegee Study"). ${ }^{57}$ Moreover, these scandals are strikingly alike in that

Liability Does Not Make Good Business Sense, 82 WASH. U. L.Q. 1593, 1596-97 (2004).

55. The NAZI Doctors AND THE NUREMBERG CODE 227-239, Oxford University Press, New York (George J. Annas \& Michael A. Grodin eds., 1992).

56. Henry Beecher, Ethics and Clinical Research, 274 NEW ENG. J. MED. 1354 (1966) (describing unethical human subject experiments conducted in the United States after World War II for the purpose of highlighting the need for greater oversight).

57. JAMES H. JONES, BAD BLOOD: THE TUSKEGEE SYPHILIS EXPERIMENT (1981) (recognized as the definitive history of the now much-documented Tuskegee Study). See also Javitt, supra note 51, at 47-49 (2005) (providing a chronological history of the events leading up to the United States' decision to adopt laws regulating human subject research). The Tuskegee Study, perhaps misleadingly named since it was funded and conducted by the U.S. Public Health Service in Tuskegee, Alabama, has become an iconic representation of the worst kind of abuse since the researchers not only failed to provide subjects with curative antibiotics, when they became available in the mid-1940's, but also instructed local doctors to turn away subjects untreated if they sought help outside of the study. See JoNES at 12. This study is portrayed in a 1992 play entitled Ms. Evers' Boys by David Feldshuh, which was made into an Emmy-winning televised movie by HBO in 1997. MISS EVERS' Boys (Home Box Office 1997). See also Miss Evers' Boys, N.Y. Univ. LITERATURE, ARTs, \& MED. DATABASE, http://litmed.med.nyu.edu/Annotation?action=view\&annid=10060 (last visited Feb. 6, 2012). See also Jerry Menikoff, Could Tuskegee Happen Today?, 1 ST. LouIS U. J. HEALTH L. \& POL'Y 311 (2008) (reviewing contemporary failures of researchers to disclose relevant information to human subjects and concluding that the contemporary IRB system is not a guarantee that subjects are provided adequate disclosure). See also Robert L. Kerr, Unconstitutional Review Board? Considering A First Amendment Challenge to IRB Regulation of Journalistic Research Methods, 11 COMM. L. \& POL'Y (SPECIAL IsSUE) 393, 393 (2006) (recounting the history of the legal regulation of human subject research in the United States). Kerr writes, "[ $[$ ] he genesis for the system of institutional review boards now in place across the United States was the revelation of shocking abuses in the Tuskegee Study on the progression of syphilis conducted between 1932 and 1972." Id. Kerr further argues that requiring IRB approval for research conducted by interviewing people violates the First Amendment, what he describes as "journalistic" research methods, since these practices would be protected from state regulation if done in the context of journalism. Id. The difference between the two activities, however, is that research studies involving interviews are funded by the federal government while interviews conducted by journalists are not. See id. Dr. Jonathan Moreno, whose foundational book Undue Risk documents the radiation experiments the United States conducted on its own citizens, suggests that the bizarre activities of sadists like Dr. Josef Mengele are horrifying, but do not reflect the magnitude of suffering and genocide. JONATHAN D. MORENO, UNDUE RISK: SECRET STATE EXPERIMENTS ON Humans 53-75 (2001). In addition to the radiation experiments, Moreno provides a history of abuses including the Army's LSD experiments and the Public Health Services' infamous Tuskegee Syphilis experiments. Moreno writes, 
almost all of them involve researchers of high repute and good will who are for some reason blind to the ethical violations of their research. ${ }^{58}$ As a result, an account of human subject research from 1945 to the present day consists of one horror story after another.

\section{HOW DRUG DEVELOPMENT OCCURS IN THE UNITED STATES}

Human subject research either funded or regulated by the Federal Government is subject to the provisions of 45 C.F.R. $\S 46.101(\mathrm{a})$, which is often called the "Common Rule" because it applies to most federal agencies including the FDA. Before human subject research can be conducted today, it must be approved by an Institutional Review Board ("IRB"). Professors Maxwell J. Mehlman and Jessica Berg summed up the process in the correct order and explained, "There are two critical steps in determining whether a medical experiment involving human subjects can be conducted in an ethical manner: assessing risks and potential benefits and obtaining potential subjects' informed consent."

\section{A. The FDA's Role of Goalkeeper}

The FDA must approve all drugs and medical devices sold in the

Some of the Nazi experiments are now so familiar as to have become a part of popular culture. Many have been morbidly fascinated by the notorious Dr. Josef Mengele, who escaped Germany for Brazil, where he lived out his life in hiding. Characters based on Mengele have even appeared in several popular movies. His sadistic experiments, such as those he performed on helpless children, especially twins, were apparently motivated by a wish to achieve an honored place in the history of medical anthropology, in 'racial science.' But the nonsense of some of Mengele's more infamous efforts, like injecting dye in brown eyes to see if he could turn them blue, is a distraction from a major portion of the abuses of the human beings in the camps-Jews, Gypsies, Poles, Russians, political prisoners, and others. For the bulk of that research was part of a systematic program in support of the Nazi war effort.

Id. at 54. Moreno warns that what should be of much more concern to us today are the equally cruel experiments that directly served the Nazi war interest by documenting the extent of human endurance in conditions such as high altitude or icy water likely to be experienced by combat troops. See id. at 60 . See generally Mary R. Anderlik \& Nanette Elster, Currents in Contemporary Ethics, 29 J.L. MED. \& ETHICS 220, 222 n.28 (2001) (quoting R. Faden and T. Beauchamp, Removing 'Deficiencies' in Human Research, BALT. SUN, Mar. 5,2000 , at $3 C$ ).

58. See SUSAN LeDerer, SUbJeCted to ScIENCE (1995) (reviewing the history of medical experimentation in the United States before World War II).

59. Maxwell J. Mehlman \& Jessica W. Berg, Human Subjects Protections in Biomedical Enhancement Research: Assessing Risk and Benefit and Obtaining Informed Consent, 36 J.L. MED. \& ETHICs 546, 546 (2008) (developing a legal and ethical framework for evaluating experiments involving human enhancement that are not intended to treat a medical condition but which have the likely result of affecting permanent change in some of the subjects). 
United States. ${ }^{60}$ The first step in extending whistleblower protection is to make such protection mandatory for all companies seeking investigational new drug approval from the FDA. The FDA reviews products submitted to it for safety and for efficacy. ${ }^{61}$ Until relatively recently, the FDA's role was primarily restricted to events occurring after human subject testing had ended. That was because medical research was limited to reviewing any applications for approval of products that were the result of the research. Increasingly, however, the FDA's role as gate-keeper to the public has resulted in its taking a more active role in the regulation of the research process. Unfortunately, even here the effect has been far less than complete protection because, although recent regulations require some disclosure, there are still serious gaps. ${ }^{62}$

The Supreme Court has twice in recent history upheld the federal government's power to make colleges and universities comply not just with federal law but also with federal policy. Bob Jones University v. United States held that the university could be stripped of its tax-exempt status if it continued its religiously based policy of banning inter-racial dating. ${ }^{63}$ Writing about the decision, Professor Martha Minnow notes that the Court did not base its decision on violation of a specific statute so much as it "reasoned that the tax exemption, as a privilege, had to comport with law and public policy; and then the Court relied on changes in American society even more than changes in legal doctrine." ${ }^{, 64}$ Since Bob Jones the Supreme Court has both enforced federal regulations, which directly target activities on campus ${ }^{65}$ and upheld the government's argument that failure to comply

60. See generally Christine D. Galbraith, Dying to Know: A Demand for Genuine Public Access to Clinical Trial Results Data, 78 Miss. L.J. 705, 713-20 (2009) for an overview of the FDA drug approval process. See also Development \& Approval Process (Drugs), U.S. FoOD \& DRUG ADMIN., http://www.fda.gov/Drugs/DevelopmentApproval Process/default.htm (last visited Feb. 8, 2012) for the FDA's own description of the drug approval process. The FDA was established in 1906 pursuant to the Pure Food and Drug Act, Pub. L. No. 59-384, 34 Stat. 768. Its regulatory authority has evolved over time. In 1938 Congress passed the Food, Drug, and Cosmetic Act of 1938, Pub. L. No. 75-717, 52 Stat. 1040, which superseded the Pure Food and Drug Act and extended the FDA's authority. Its enabling statute has been further amended since.

61. 21 U.S.C. $\S 355(d)(5)$ (2008) (requiring that pharmaceutical companies provide "substantial evidence" of their product's efficacy). Today, "data from one adequate and well-controlled clinical investigation and confirmatory evidence (obtained prior to or after such investigation) are sufficient to establish effectiveness ... . [and] to constitute substantial evidence." Id. (corresponding to the Food and Drug Administration Modernization Act of 1997, Pub. L. No. 105-115, § 103, 111 Stat. 2296 (1997)).

62. See, e.g., Galbraith, supra note 60 , at 741-51 (criticizing U.S. federal clinical trials results database as not adding significantly to the public's knowledge).

63. Bob Jones Univ. v. United States, 461 U.S. 574, 605 (1983).

64. Martha Minnow, Should Religious Groups Be Exempt From Civil Rights Laws?, 48 B.C. L. REV. 781, 797 (2007) ("The opinion reasoned, '[T] here can no longer be any doubt that racial discrimination in education violates deeply and widely accepted views of elementary justice."' (quoting Bob Jones Univ. v. U.S., 461 U.S. 574, 594 (1983))).

65. Rumsfeld v. Forum for Academic \& Institutional Rights, Inc., 547 U.S. 47, 60-61 
with federal policy could result in the complete elimination for eligibility of all federal funding including financial aid and research grants.

\section{B. The FDA's Rule Making Authority}

The FDA has the authority to issue its own rules so long as they support the intent of the statutes and regulations which they are intended to enforce. While all Executive Branch Agencies have this power, the FDA has more ability than most because there is no requirement that it engage in negotiated rule-making with outside stake-holders. ${ }^{66}$ No drug can be sold in the United States without the approval of the FDA. ${ }^{67}$ This approval comes through submission of an Investigational New Drug application, which is supported by research intended to prove to the FDA's satisfaction that the proposed drug is both safe and effective. ${ }^{68}$ By setting standards for acceptability of supporting research, the FDA has considerable control over the way research studies are conducted. ${ }^{69}$

For example, because the FDA requires that psychiatric drugs be proved effective in comparison to no treatment at all, anyone seeking to gain approval for a new psychiatric drug must conduct human subject trials in which some patients receive a placebo, no treatment, and others the ac-

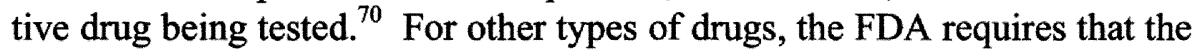
new drug be treated against the current best available treatment. Thus, a company wishing to market a new blood pressure medication need not set up a trial in which some patients with high blood pressure receive no treatment at all while others receive the new drug. It does this by establishing its own criteria for the contents of Investigational New Drug applications. ${ }^{71}$ Therefore, all research intended to result in a drug to be sold in the United States comes under the jurisdiction of the FDA. ${ }^{72}$ Research funded directly by the federal government is also subject to separate, and often different, regulations. As a practical matter, this means that privately funded human subject research that will not be used to support an Investigational New Drug application and is not conducted in or by an institution that receives

(2006) (holding that private universities must allow military recruiters on campus or risk eligibility for all federal funding).

66. Julia Kobick, Negotiated Rulemaking: The Next Step In Regulatory Innovation At The Food And Drug Administration?, 65 FooD \& DRUG L.J. 425, 434 (2010) ("FDA has never voluntarily convened a rulemaking negotiation, and Congress has never statutorily mandated that FDA establish an ad hoc negotiated rulemaking committee.").

67. W. Christopher Matton \& F. Scott Thomas, The Continuing Balance: Federal Regulation of Biotechnology, 44 JURIMETRICS J. 283, 293-94 (2004).

68. Id. at 295-96.

69. Id. at $297-98$

70. See Steve Silberman, Placebos Are Getting More Effective. Drugmakers Are Desperate to Know Why., WIRED (Aug. 24, 2009) ("Today, to win FDA approval, a new medication must beat placebo in at least two authenticated trials.").

71. Matton \& Thomas, supra note 67, at 295-96.

72. Id. at 294. 
federal funding is essentially unregulated. ${ }^{73}$

\section{Existing FDA Protections Insufficient to Protect Research Subjects}

Congress has tried to address the problem of suppression of both harm to human subjects and negative information stemming from the trial by requiring those interested in eventual FDA approval to register studies in advance. The result has been a series of new regulations, starting in 1997 with the Food and Drug Administration Modernization Act, ${ }^{74}$ which require the actual registration of trials but do not require information about results. ${ }^{75}$

Current regulation requires that sponsors of "controlled clinical investigations" of "Drugs and Biologics" must register their clinical trials at the website ClinicalTrials.gov in accordance with section 801 of the Food and Drug Administration Amendments Act of 2007 (FDAAA). ${ }^{76}$ Seeing this requirement coming, many drug companies have voluntarily developed their own trial registries in which they promise to publicize the results of their drug trials, but in the absence of comprehensive regulation these registries contain no more than what the company wishes to disclose. ${ }^{77}$ However, the obligation to register trials does not extend to posting reports of

73. Federal law says nothing about the extent of its application to research conducted at a stand-alone research facility, such as a biotechnology company, which is entirely privately funded. Given the absence of any action by the federal government, it is fair to assume that private facilities are unregulated although of course bound by the requirements of local criminal and tort law. See Matton \& Thomas, supra note 67, at 319 ("[I]t is currently unclear whether DHHS would consider extending the scope of its regulatory jurisdiction to encompass privately funded biotechnology-related research where equipment or other facilities used by participating academic or private corporations were previously funded by unrelated federal grants. Current DHHS regulations simply do not address this issue.").

74. Food and Drug Administration Modernization Act of 1997, Pub. L. No. 105-115, $\S 301,111$ Stat. 2296.

75. See id.

76. See Nat'L Insts. OF Health, FaCt SheET: Registration at CliniCALTRIALS.GOV (2009), available at http://prsinfo.clinicaltrials.gov/s801-factsheet.pdf; Public Meeting on Expansion of the Clinical Trial Registry and Results Data, 74 Fed. Reg. 12138 (Mar. 23, 2009), available at http://prsinfo.clinicaltrials.gov /Clinical_Trials_FRN31609_POST.pdf; Bridget M. Kuehn, Clinical Trials Registry Expands, 302 JAMA 1, 22 (2009); see generally Principals of Medical Research and Clinical Trial Registry, FDA.Gov, http://www.fda.gov/ohrms/dockets/ac/04/briefing/2004-4065b129-lilly-Attachment-2-Clinical-Trial-Registry.pdf (last visited Aug. 1, 2009); see also Food and Drug Administration Amendments Act of 2007, Pub. L. No. 110-85, § 301121 Stat. 823, 922 (further broadening FDA's authority to do post-market testing).

77. Merck KGaA has promised to make the basic results of its trials (except Phase I) available on a publicly accessible database (clinicaltrials.gov results database). This applies to trials with a product for which approval for marketing in a single country has been received, irrespective of the location and outcome of the trials. MERCK, MERCK PERSPECTIVE: Clinical Trial Registries and the Publication of Clinical Trials (2012), http://www. merck.com/research/discovery-and-development/clinical-development/Merck-PerspectiveClinical-Trials.pdf (last updated Jan. 2012). 
adverse events. Pharmaceutical companies are reluctant to do this because such information would damage them commercially either by giving information to their competitors or by exposing them to liability or by causing damage to their reputation. ${ }^{78}$

One of the most substantial of these is the failure of a legal requirement to report adverse events during a clinical trial. ${ }^{79}$ After reviewing what they describe as "several hundred clinical trial registries around the world" the philosophers concluded that "[a]1l of these policies fall short of ensuring that adverse clinical trial results are disclosed to prospective participants in clinical trials." ${ }^{80}$ Their power to do that comes in the form of requiring applicants to certify that specific conditions were met in the research and development process. ${ }^{81}$ One of the on-going problems in regulating medical research is that there has been no legal obligation for anyone conducting such research to disclose information to the FDA before submitting an application for approval. ${ }^{82}$

A study conducted at a publically funded institution or with government funds would have to be reviewed by an Institutional Review Board at the home institution, but even then, the process is an internal one without outside review. ${ }^{83}$ A private company or an entity outside of the United States has no legal obligations whatsoever to make any disclosures unless it seeks to market the product of the research in the United States. ${ }^{84}$ That means if no application for approval is filed, no one would ever know that the study took place.

\section{FDA Authority to Regulate Clinical Trials}

Since the FDA already has statutory authority to regulate the testing and marketing of prescription drugs, individual states are preempted from imposing conflicting obligations. ${ }^{85}$ They may, however, require greater protections for human subject research taking place within their boundaries. ${ }^{86}$ Several states have already passed laws regulating human subject

78. See S. Matthew Liao et al., The Duty to Disclose Adverse Clinical Trial Results, 9 AM. J. Bioethics 24, 24 (2009) (discussing the general harm of disclosing adverse clinical results).

79. See id. (developing arguments for "a moral duty to disclose all relevant adverse clinical trial results that involve harms to prospective participants in clinical trials").

80. Id. at 27 .

81. Id.

82. Id.

83. Carl H. Coleman, Research with Decisionally Incapacitated Human Subjects: An Argument for a Systemic Approach to Risk-Benefit Assessment, 83 IND. L.J. 743, 757 (2008).

84. See S. Matthew Liao et al., The Duty to Disclose Adverse Clinical Trial Results, 9 AM. J. OF BIOETHICS 24, 27 (2009).

85. See Coleman, supra note 83 (describing the current system of regulation).

86. Id. at 760 . 
research occurring within their borders, regardless of funding source. ${ }^{87}$ While it would be possible for Congress to pre-empt state regulation and extend similar protections, so far this has not happened. ${ }^{88}$

However, when confronted with harm to research subjects, states can and do apply common law tort and contracts remedies to compensate the injured. ${ }^{89}$ Physical harm to subjects is actionable under either criminal or tort law. Notwithstanding, so far there are no recorded cases of a state making a criminal referral. ${ }^{90}$

It was Congress's choice at the time to regulate only human subject research funded by the government and not to extend protection to all human subjects of research regardless of how the research was funded. ${ }^{91}$ This choice set up the fragmented system in which federally funded research, which is intended to support a petition to the FDA, is regulated differently than all other human subject research, if there is any regulation at all. The current legal structure regulating human subject research supported by federal funds was passed into law in 1981 and incorporates the National Research Act of 1974, the 1976 Senate Hearings and the statement of definitions and ethical principles set out by the National Commission for the Protection of Human Subjects of Biomedical and Behavior Research in what is known commonly as the "Belmont Report." The Belmont Report

87. See Grimes v. Kennedy Krieger Inst., Inc., 782 A.2d 807 (2001). The Maryland Court of Appeals held that in this instance, summary judgment was not appropriate to determine whether the Kennedy-Krieger Institute, a Johns Hopkins affiliated research organization, violated Maryland tort law and contract law. Id. at 813. Because the researchers had a special relationship with the research subjects, the court stated that there is a heightened duty, which was breached by giving inadequate informed consent. Id. at 846. Additionally the consent forms omitted material information. Id. at 844. See generally Paul Litton, NonBeneficial Pediatric Research and the Best Interests Standard: A Legal and Ethic Reconciliation, 8 YALE J. HEALTH POL'Y, L. \& ETHICS 359, 378-82 (2008) (describing the litigation); L. H. Glantz, Nontherapeutic Research with Children: Grimes v. Kennedy Krieger Institute, 92 AM. J. PUB. HEALth 1070, 1070-73 (2002); Anna C. Mastroianni \& Jeffrey P. Kahn, Risk and Responsibility: Ethics, Grimes v. Kennedy Krieger, and Public Health Research Involving Children, 92 AM. J. PUB. HEALTH 1073, 1073-76 (2002).

88. "Today almost every state has whistleblower statutes, and virtually all environmental bills contain whistleblower provisions. They may be exercised in both the public and the private sectors." Dawn R. Franklin, The Outsiders: Broadening the Scope of Standing in Whistleblower Actions in Light of Anderson v. United States Department of Labor, $20 \mathrm{~J}$. NAT. RESOURCES \& ENVTL. L. 281, 281 (2006).

89. Jay M. Zitter, Annotation, Recovery for Nonconsensual Human Medical Experimentation, 42 A.L.R. FED. 301 (2009).

90. See L. Song Richardson, When Human Experimentation is Criminal, 99 J. CRIM. L. \& CRIMINOLOGY 89, 98, 107 (2009), who criticizes the reluctance to seek criminal penalties against researchers who cause the harm of subjects either without adequate informed consent or in ways that make consent irrelevant. ("Punishing culpable researchers would send a clear message: violations of autonomy and dignity are wrong whether or not they take place in the context of socially beneficial research.").

91. 42 U.S.C. $\S 289$ (2011).

92. Jesse A. Goldner, Regulating Conflicts Of Interest In Research: The Paper Tiger Needs Real Teeth, 53 ST. LouIs U. L.J. 1211, 1215-17 (2009). 
outlined the ethical principles by which human subject research should be governed. ${ }^{93}$ This included familiar references to the Helsinki Accord such as respect for persons and the necessity for informed consent. ${ }^{94}$

\section{E. How FDA Oversees Clinical Trials}

Every drug sold in the United States must first be approved by the FDA's Center for Drug Evaluation and Research (CDER). The approval process involves filing an application for a new drug. ${ }^{95}$ The company seeking approval (the Sponsor) must submit the human and animal clinical trials on which it is basing its representation that the drug being offered is both safe and effective. The FDA's ability to oversee the safety of humans in drug trials comes from its authority to require the submission of study results. ${ }^{96}$

Research for every drug that eventually reaches the American public starts with a scientist's idea and proceeds through a series of testing phases until the FDA is convinced that it is both safe and effective. It is described as non-therapeutic research because this initial testing is usually done on healthy volunteers who do not suffer from the conditions the drug being tested is designed to treat. ${ }^{97}$

Human subject research intended to support an application for sale of a new drug in the United States is regulated differently from human subject research funded by the federal government intended to increase the general fund of knowledge. The FDA requires those conducting clinical trials to follow Good Clinical Practices (GCP), which are similar, but not identical to OHRP's requirements for federally funded human subject research. ${ }^{98}$ Both activities come with inherent, if different, conflicts of interest.

Although both the Office of Human Research protection and the FDA have the statutory authority to over-see research trials, both are under-

93. Jacqueline Fox, Reinvigorating the Concept of Benefit: The Failure Of Drug Company-Sponsored Research on Human Subjects, 38 SETON HALL L. REV. 605, 606 (2008).

94. The way bioethicists have influenced the law of human subject research is apparent in reviewing how the Human Subject Research Regulations have evolved since 1974. Carl H. Coleman et al., The Ethics and Regulation of Research with Human Subjects 723 (2003).

95. 31 C.F.R $\$ 314$ (1998) (requirements for filing a new drug application).

96. Coleman et al., SUPRA NOTE 94.

97. Douglas A. Grimm, Informed Consent for All! No Exceptions, 37 N.M. L. REV. 39, 53 (2007) (explaining that for most analytical or evaluative purposes, human subject research is divided into two categories: therapeutic and non-therapeutic).

98. For an overview of these differences see Comparison of FDA and HHS Human Subject Protection Regulations, U.S. FoOD \& DRUG ADMIN., http://www.fda.gov/ ScienceResearch/SpecialTopics/RunningClinicalTrials/EducationalMaterials/ucm112910.htm (last updated Mar. 10, 2009). See generally J. Tori Evans, Clinical Trial Data Bank: The Missing Link In The Dissemination Of Information To The Medical Community, 9 QUINNIPIAC HEALTH L.J. 69, 73-76 (2005) (a history of how the FDA developed into its present day role of evaluating the safety and efficacy of prescription drugs). 
funded and stretched thin. Critics Adile Shamoo and Paul Gelsinger note that, "Last year, a report by the [I]nspector [G]eneral of the Department of Health and Human Services found that the FDA, the agency responsible for overseeing most clinical trials, inspected just 1 percent of study sites." These inadequacies and gaps are compounded in the area of drug research, development, and sales because even when laws exist to encourage disclosure, they are often predicated on reporting specific violations of the law. Since research itself is so inconsistently regulated, a danger to the public's health may well not violate any existing statute or regulation and therefore the person reporting it would not be eligible for whistleblower protection under any law now in effect anywhere in the country.

\section{F. Dangers Arise in all the Four Phases of FDA Regulation}

\section{Phase One and Two: Non-Therapeutic Research}

The FDA pursuant to its rule making authority establishes these stages of testing. The first time a potential drug can be tested on human is in Phase One studies, which the FDA describes as being typically "designed to determine the metabolism and pharmacologic actions of the drug in humans, the side effects associated with increasing doses, and, if possible, to gain early evidence on effectiveness." 100 Since the purpose of a Phase One trial is to test the toxicity of a drug, the dangers to research subjects may be considerable.

Until a series of scandals in the late 1970 s put an end to the practice, most Phase One testing in the United States was conducted on prisoners. ${ }^{101}$ Without access to prisoners, researchers looked for other large groups of healthy adults with plenty of time on their hands and discovered college students ${ }^{102}$ and homeless people. ${ }^{103}$ Today, Phase One trials are primarily conducted by pharmaceutical companies in standalone research facilities

99. Paul Gelsinger \& Adil E. Shamoo, Eight Years After Jesse's Death, Are Human Research Subjects Any Safer?, HASTINGS CENTER REPORT, Apr. 2008, at 25-27, available at http:/humansubjects.energy.gov/news/articles/04002008.EightYears_ac.pdf.

100. 21 C.F.R. $\$ 312.21$ (a) (2008).

101. Coleman et al., SUPRA NOTE 94. For a history of the scandals which led to prisoners being no longer available as human subjects in Phase One drug trials, see ALLEN HORNBLUM, ACRES OF SKIN: HUMAN EXPERIMENTS AT HOLMESBURG PRISON (1999); see also Keramet Reiter, Experimentation On Prisoners: Persistent Dilemmas in Rights and Regulations, 97 CALIF. L. REV. 501 (2009).

102. See generally Heather Munro Prescott, Using the Student Body: College and University Students as Research Subjects in the United States During the Twentieth Century, 57 J. HIST. MED. \& ALLIED SCI. 3 (2002). College students have long been a source of human research subjects conducted in Universities. The distinction is in their specific recruitment for Phase One and Two trials conducted by pharmaceutical companies.

103. Tom I. Beauchamp et al., Pharmaceutical Research Involving the Homeless, $27 \mathrm{~J}$. MED. \& PHIL. 547, 547-64 (2002) (detailing increased use of the homeless in medical research and considering ethical concerns about coercion in obtaining informed consent). 
located near universities, which provide large numbers of healthy subjects willing to endure some discomfort and inconvenience in exchange for cash. These centers advertise heavily, promising high pay for little effort. In times of economic hardship, the pool of potential subjects widens beyond college students to include unemployed adults with no other way of making a living.

For many, being subjects in Phase One medical research has become a way of life. They self-identify as "Guinea Pigs" and have their own website in which they rate different companies' research facilities and share their experiences. ${ }^{104}$ Writing about the phenomena of "Guinea Pigging" in the New Yorker, Carl Elliott explains, "[u]nlike subjects in later-stage clinical trials, who are usually sick and might enroll in a study to gain access to a new drug, people in healthy-volunteer studies cannot expect any therapeutic benefit to balance the risks they take." ${ }^{105}$ One experienced Guinea Pigger emphasized that this was a commercial transaction, not a contribution to society stating, "[n]obody's doing this out of the goodness of their heart."106

\section{Phase Three and Four: Therapeutic Research}

Unlike Phase One and Two trials, which are done using healthy volunteers, Phase Three and Four trials are called therapeutic research because they are conducted with sick volunteers. It too takes place in stages. If a drug is found safe, then the company moves on to Phase Two trials which, according to FDA regulation, "includes . . . controlled clinical studies conducted to evaluate the effectiveness of the drug for a particular indication or indications in patients with the disease or condition under study and to determine the common short-term side effects and risks associated with the

104. Guinea Pig Zero: A Journal for Human Research Subjects, http://www.guineapigzero.com/ (last updated May 23, 2008). In 2002, selections from the website were compiled into a book, GUINEA PIG ZERO edited by Robert Helms. See GUINEA PIG ZERo: AN ANTHOLOGY OF THE JourNal For HUMAN RESEARCH SUBJECTS (Robert Helms ed., 2002).

105. Carl Elliott, Guinea-Pigging, THE NEw YORKER (Jan. 7, 2008), http://www. newyorker.com/reporting/2008/01/07/080107fa_fact_elliott\#ixzz0vy5EdRCy.

106. Id. Writing in Guinea Pig Zero, another man explained that he was "once paid fifteen hundred dollars in exchange for three days and two G.I. endoscopies at Temple University, where he was given a private room with a television. 'It was like a hotel,' he says, "except that twice they came in and stuck a tube down my nose." Id. Another described a two-week study for which he received 1500 dollars as a way of funding his backpacking trip across the country. He writes,

It's great: you get a simple physical, a place to stay, fed at least once a day, an opportunity to catch up on TV shows, and the whole time you are getting paid. The price? Surrender your freedom. You give a lot of blood. Pussies to the needle need not apply.

Guinea Pig Zero: An ANTHOlogy of the Journal for human Research SubJects 34, (Robert Helms ed., 2002). 
drug." ${ }^{107}$ All patients in Phase Two trials are in need of treatment for a specific condition. However, their interest in enrolling in a clinical trial varies considerably depending on the nature of their illness.

For people who lack medical insurance yet suffer from conditions that are distressing but not life threatening, a clinical trial may be their only way of getting treatment. ${ }^{108}$ For them, too, the decision to enter a research study is financial. Explaining his decision to enroll in an insomnia study, a man without insurance explained, "I saw an ad that had to do with insomnia. I didn't have medical insurance at the time so it's not like I could go see a doctor because it really wasn't cost effective with prescription drugs .... . And I figured, well, the drug's not proven yet, but I just rolled the dice.,"109

There are other even more vulnerable participants in Phase Three trials, who are not seeking care they cannot afford, but rather have serious and life threatening conditions and are seeking treatments which would be unavailable to them outside of a clinical trial. They, too, may hope and expect to benefit from the possibility of access to drugs otherwise not available to them. ${ }^{110}$

The third category of participants in Phase Three trials are also quite vulnerable because they are so sick that they have very little hope or expectation that they themselves will be helped by the drug they are testing. Rather, they participate in order to help people in the future who suffer from the same condition. In theory, these latter subjects are true altruists who participate in order to help future patients.

The vulnerabilities of these subjects have a common feature: they all believe that the research study in which they are participating will improve

107. 21 C.F.R. $\S 312.21$ (2011).

108. The ability of terminally ill patients to enroll in a research trial in order to obtain access to experimental drugs has become a topic of considerable interest and dispute. The D.C. Circuit held that individuals had no right to access drugs only available through clinical trials. Abigail Alliance v. von Eschenbach, 445 F.3d 470 (D.C. Cir. 2007) (en banc), cert. denied, 552 U.S. 1159 (2008); see also Elizabeth Weeks Leonard, The Public's Right to Health: When Patient Rights Threaten the Commons, 86 WASH. U. L. REV. 1335, 1384 (2009) (arguing that while the Supreme Court's denial of cert suggests that this will not any time soon be recognized as a fundamental right, Professor Elizabeth Weeks Leonard has advanced the theory of a "Public Health Right" which "contemplates that the public, as a body, merits protection from interference by individual members of society. In the case of access to experimental drugs, the potential harm to so many other patients who also await the promise of a cure or benefit from scientific developments, justifies the decision to deny access to experimental drugs to currently terminally ill patients.").

109. Jill A. Fisher, Medical Research for Hire: The Political Economy of Pharmaceutical Clinical Trials 135 (Rima D. Apple \& Janet Golden eds., 2009).

110. Grimm, supra note 97, at 57. In fact, almost all subjects in research studies believe that participation in a study might be of direct benefit. "The purpose of therapeutic research is 'to directly help or aid a patient who is suffering from a health condition the objective of the research are designed to address." Grimes v. Kennedy Krieger Inst., Inc., 782 A.2d 807, 811 n.2 (Md. 2001). 
their health. ${ }^{111}$ This is a fundamental mistake since all research is intended to advance knowledge and any benefit to an individual subject is incidental. It is this misconception that the research will help them that is of most interest to ethicists who are far ahead of the law in expressing their concern. While it is certainly true that very sick patients benefit every day from new treatments only available through a research study, the purpose of this study is to assess the effectiveness of the treatment, not treat the research subject. The difference is emphasized in language where the people receiving the experimental treatments are described as subjects, not patients. ${ }^{112}$ A finding that the new treatment does not, in fact, improve patient outcomes is as much a success as one that finds the opposite. An unsuccessful study is one that provides no conclusive results either way.

Thus, even studies described as being of "direct-benefit" to the patients involved, "[a]re, however, not medical treatment because "while subjects may receive therapeutic benefits from participating ... providing direct benefits to subjects is not the purpose of the research." Instead, as with all research, the primary goal is to "develop generalized knowledge that may ultimately translate into beneficial treatments for patients in the future." "[T] "To make the results of a study generalizable, researchers rely on a variety of methodological features that can create risks that do not exist when a person receives individualized medical treatment outside of a study."114 For example, subjects in a therapeutic study may be subject to blood draws, lumbar punctures, ${ }^{115}$ and other invasive procedures intended to

111. A consistent critic of human subject research is attorney Allan Milstein, who believes that patients' hopes for a cure are exploited. See Jennifer Washburn, Informed Consent: One Lawyer's Assault on the Medical Research Establishment, WASH. Post MAG., Dec. 30, 2001, available at http://newamerica.net/node/5969.

112. For a powerful literary portrayal of this dichotomy, see Margaret Edson's play Wit, which is told from the perspective a college professor who, faced with an incurable cancer, undergoes a painful trial of an experimental drug without fully understanding that it is of no benefit to her. See CAROL COHEN, MARGARET EDSON's WIT - AN AUdIENCE GUIDE (2000), available at http://faculty.smu.edu/tmayo/witguide.htm.

113. Id.

114. Coleman, supra note 83 , at 751 (emphasis in original) (citing 45 C.F.R. $\S$ 46.102(2) (2008)) (defining "research" as a "systematic investigation, including research development, testing and evaluation, designed to develop or contribute to generalized knowledge"); Carl H. Coleman, Duties to Subjects in Clinical Research, 58 VAND. L. REV. 387, 396-402 (2005); see also Litton, supra note 87, at 362 ("[One] must carefully distinguish the purpose of research from the purpose of medical care. Medical care aims to promote an individual patient's well-being. Research aims to produce generalizable knowledge.").

115. See Coleman, supra note 83, at 751 n.36 ("[L]umbar punctures (spinal taps) ... while usually safe, [are] known to carry a risk of 'serious neurological sequelae."') (quoting A. Strachan \& J. Train, Letter to the Editor, Lumbar Puncture and Headache: Aspirating Cerebrospinal Fluid Speeds up Procedure, 316 BRIr. MED. J. 1015, 1018 (1998)); see also Litton, supra note 87 , at 374-75 (describing a study comparing current treatment of renal disease to experimental therapy, and stating that "[T]he group receiving the experimental intervention is put at no more risk than the children receiving standard therapy. However, all pediatric participants will be subject to a regimen of blood draws that are not clinically- 
gather more data than would be necessary in a purely treatment setting. ${ }^{116}$

\section{The Particular Dangers in Stages Three and Four: Dangers from the Therapeutic Misconception}

Because stage Three and Four trials of therapeutic research are conducted with people who are sick, there is inevitably entanglement between the doctor's role as researcher and personal physician. This entanglement leads to a state called the

therapeutic misconception [which] arises when re-
search participants confuse the objective of research,
which is to generate knowledge, with the objective of
therapy, which is to benefit the individual patient. In
this situation, some may enroll in studies with the
mistaken belief that each study component is aimed at
patient care, rather than knowledge production. ${ }^{117}$

Part of the confusion is because clinical research often takes place in settings such as treatment hospitals and doctors' offices and the medical personnel administering the study are indistinguishable, and indeed often identical to, the people providing treatment. ${ }^{118}$

There is a considerable literature that comes to very little agreement of what a researcher's obligations are to a patient as opposed to a physician. ${ }^{119}$

indicated; these blood draws are for research purposes only, conducted to monitor changes in the chemical values within the participants' blood, as well as to monitor their compliance with the protocol.").

116. Id. See also Peter R. Breggin \& Ginger Ross Breggin, Talking Back to Prozac: What Doctors ARen't Telling You About Today's Most Controversial DRUG 42 (1994) (criticizing that the testing of Prozac against a placebo made "[the] drug seem more effective than it is" because those who responded to the placebo were dropped and replaced with other subjects. Thus, it is impossible to know how many more people actually responded positively to the drug as opposed to the placebo).

Coleman, supra note 83, at 752 n.37 (citing CARL H. COLEMAN ET AL., THE ETHICS AND REGULATION OF RESEARCH WITH HUMAN SUBJECTS 271 (2005)). The risks of participating in Phase Two and Three trials of new psychiatric medications is even greater than that of other trials because regardless of the potential benefit of the new drug, all subjects must be completely withdrawn from any other psychiatric medications before starting the trial. This process, known as a "washout" is often so dangerous that the subject needs to be hospitalized. Even after washout a patient may receive no treatment at all because her regular medications are replaced with a placebo.

117. Id. at 752 .

118. Rebecca Dresser, The Ubiquity and Utility of the Therapeutic Misconception, 19 SOC. PHIL. \& POL'Y 271, 293 (2002) ("[To] erode the therapeutic misconception . . . drastic change will be required. First, to counter the pervasive characterization of trials as treatment, researchers must give patients stark, bold, and dramatic signs that research is different from clinical care. Simple environmental changes could have a strong impact on patient perceptions. For example, instead of the white coats associated with medical care, investigators could wear red ones.").

119. See, e.g., Coleman, supra note 94; Gerald S. Schatz, Ethical Lawyering in the 
This is a particularly difficult problem when both physician and researcher are the same person. Traditionally, the discussion starts with the concept of consent. ${ }^{120}$ Federal law requires that all human subjects in federally funded research studies be informed of the risks and benefits they face. ${ }^{121}$ Yet, is being informed the same as having consented?

One of the greatest problems faced in protecting human subjects is the inherent vulnerability of all potential subjects regardless of age, education, or legal status, which prevents their ability to withhold freely consent. Another is the inherent trust people have in their doctors. As Professor Rebecca Dresser, one of the leading experts in legal and ethical issues concerning human subject research, writes, the "therapeutic misconception conflicts with the long-standing and widely accepted research ethics principle of respect for persons" because it takes advantages of the trust people already have in doctors as healers. For this reason, everyone, not just specifically identified sub-populations, is vulnerable to when asked to consent to being a research subject. ${ }^{122}$ It is easy to see why the institutionalized ${ }^{123}$ the cognitively impaired, ${ }^{124}$ the young, and the socially marginalized ${ }^{125}$ need extra

Protection of Human Subjects of Biomedical and Behavioral Research, 13 MiCH. ST. U. J. MED. \& L. 151 (2009).

120. See Moore v. Regents of the Univ. of Cal., 793 P.2d 479 (Cal. 1990). The concept of what a patient has or has not consented to in terms of research can often have significant financial implications. Almost every first-year law student reads the case of Moore v. Regents of the Univ. of Cal., in which the California Supreme Court held that a patient did not own the rights to a highly profitable cell line developed from tissue removed from his body during a medically necessary operation. Id.

121. 21 C.F.R. $\$ 50.20(2007)$.

122. Dresser, supra note 120.

123. Id.

124. The aging of the United States population and the corresponding rise in rates of dementia has made designing appropriate methods of conducting research with people who lack decision-making capacity a matter of considerable urgency and debate. As Professor Carl Coleman writes,

[m] edical research with persons who lack decision-making capacity is in a state of crisis ... [and] in most states, it takes place without any clear regulation. As a result, few, if any, safeguards exist to protect the rights and welfare of incapacitated research subjects, and surrogates who are asked to provide consent on behalf of incapacitated persons have no meaningful standards to help them determine whether they are making the right choice. Moreover, the lack of legal authorization for this research means that those responsible for the studies-both the researchers and the surrogates who provide consent-risk substantial liability when, as will inevitably occur, an incapacitated subject suffers injury and a lawsuit results.

Coleman, supra note 83, at 744.

125. See Rebecca Dresser, Patient Advocates in Research: New Possibilities, New Problems, 11 WASH. U. J.L. \& POL'Y 237, 240 (2003) (citing Rebecca Dresser, The Ubiquity and Utility of the Therapeutic Misconception, 19 Soc. PHIL. \& POL'Y 271 (2002)) (suggesting that patient advocates in research trials may or may not help avoid the problem of patients developing " $[t]$ he therapeutic misconception-a phenomenon that occurs when people do not understand the aims and methodological requirements of biomedical research. The primary purpose of research is to gain knowledge that will improve care for future patients, not to deliver treatment tailored for an individual patient. When research and treatment are 
protection, but in fact everyone, sick or well, is in a position of relative powerlessness when dealing with respected authority figures such as doctors or researchers. When asked about their experience, research subjects almost universally endorse the belief that the activities of the study are intended for their personal benefit. ${ }^{126}$ This is, of course, especially true when the subject is sick and is participating in research that may, indeed, be of benefit. Even in studies with well people, no type of pre-study consent materials seems to be sufficient to get subjects to endorse the statement that the study is of no benefit to them whatsoever. ${ }^{127}$ Even if the study does not cause harm its lack of benefit is reason for concern because of what Professor Richard Saver identifies as "intangible harm" suffered by research subjects who are expecting to be treated. ${ }^{128}$ He writes that "[e]xperimentation activity in the face of near-complete misunderstanding by subjects of what research participation means risks objectifying subjects as mere specimens or pieces of data." 129 But, if the researcher and the doctor are the same person, is it possible to have different obligations to the research subject and to the patient, who are also the same person ${ }^{130}$

confused, patients may enroll in research studies without a good understanding of the tradeoffs involved. Such patients may have an unrealistic hope for personal benefit without recognizing the risks and uncertainties accompanying their participation in the studies.").

126. Dresser, supra note 27 , at $45-46$.

127. Id. at 42.

128. See generally Richard S. Saver, Medical Research and Intangible Harm, 74 U. CIN. L. Rev. 941 (2006).

129. Id. at $945-46,1000$. Professor Saver explains that while available data suggests that participating in a recent study does not significantly increase an individuals' chances of suffering physical harm or of being put in a worse medical condition than if he or she had not enrolled,

[a] research subject faces a range of serious potential hazards that may materialize even if participation in the experiment has not made the subject therapeutically any worse off than if she had not enrolled. This harm includes not only emotional distress, but also lost opportunity costs, destruction of trust and confidence in the research process, clinical trial abandonment, affront to dignitary interest, breach of confidentiality, invasion of privacy, loss of meaningful choice about use of one's body as an experimental object, participation in a study that fails to disseminate trial data in order to advance medical knowledge, and frustrated access to perceived cutting-edge therapy.

Id. at 945-46. The status of a human research subject is itself a subject of considerable debate. Contemporary ethicists and lawyers like Richard Saver believe that subjects should be seen as "partners" or "co-adventurer[s]" with the researchers rather than as passive objects of study. Id. at 1007 . While there are researchers who conduct studies as joint-ventures, most have not adopted this view and, indeed, see the idea of actively involved subjects as an unnecessary complication.

130. There are two main points of view. One is most often associated with U.S. law professor Fran Miller and ethicist Dr. Howard Brody who believe that research and medical care are quite different and therefore the obligations of a researcher are not those of a physician. See, e.g., Franklin G. Miller \& Howard Brody, A Critique of Clinical Equipoise: Therapeutic Misconception in the Ethics of Clinical Trials, HASTINGS CENTER REPORT, May-Jun. 2003, at 19-28; Franklin G. Miller, Research Ethics and Misguided Moral Intuition, 32 J. L. MED. \& ETHICS 111, 111-16 (2004). However, Canadians Paul B. Miller and Charles Weijer step outside this traditional consent based analysis to point out that whether the relation- 
These activities are, unfortunately, common. In a series of front page articles, the New York Times reported in the summer of 2010 that GlaxoSmithKline conducted secret tests which confirmed rumors of heart problems associated with the drug Avandia. In a document obtained by the New York Times, an executive wrote in a 2001 internal email, "This [the test] was done for the U.S. business, way under the radar . . . . Per Sr. Mgmt request, these data should not see the light of day to anyone outside of [the company]."131 Even more disturbing than the company's own efforts to hide the dangers was the cooperation of a prominent physician associated with a respected academic medical center who lent his name to an article supporting use of Avandia in medical journals which company records describe as being "ghost-written" for him. ${ }^{132}$

In August 2005, a jury in Brazoria County, Texas, found Merck \& Co., the manufacturer of VIOXX, liable for the death of the plaintiff Robert Ernst after a six-week trial. The jury concluded that "Merck failed to warn doctors of the dangers of VIOXX, and that Merck's negligence caused the death of Ernst, a physically fit tri-athlete who suffered a sudden heart attack." "133 Interviewed afterwards, the "jurors said they had concluded from the testimony and documents presented by Mrs. Ernst's lawyers that Merck was long aware of Vioxx's potential heart risks but hid those risks from patients."134

The costs of suppressed information about potential dangers extend beyond those actually injured by the drugs. It all results in higher prices for consumers of these drugs because of higher research and development costs

ship is between doctor and patient or researcher and patient, it is one of "personal trust" in which there is an inherent inequality between the parties which results in "dependence generated by the voluntary act of entrusting power to another. Paul B. Miller \& Charles Weijer, Trust and Exploitation in Clinical Research, in THE LIMITS OF CONSENT: A SOCIO-ETHCAL APPROACH to Human SubJeCt RESEARCH IN MEDICINE 31(Oonagh Corrigan et al. eds., 2009). They note that this trust relationship creates a "moral obligation" equivalent to the "fiduciary relationship" between an attorney and client. Id. Miller and Weijer conclude that this inequality, which creates a "distinctive risk of exploitation," creates the same "duty of care" in a researcher as in a physician. Id. at 36 .

131. Harris, supra note 5.

132. Paul Baskin, Baylor College of Medicine Investigates Professor Over Avandia Article, CHRON. HIGHER EDUC., July 16, 2010, available at http://chronicle.com /article/Baylor-College-of-Medicine/66308.

133. LANIER LAW FIRM, http://www.indeed.com/cmp/Lanier-Law-Firm (last visited Nov. 20, 2011); see also Marc Kaufman, Merck Found Liable in Vioxx Case: Texas Jury Awards Widow \$253 Million, WASH. Post, Aug. 20, 2005, available at http://www.beasleyallen.com/news/merck-found-liable-in-vioxx-case-texas-jury-awardswidow-253-million/.

134. Alex Berenson, For Merck, Paper Trail Won't Go Away, N.Y. Tumes, Aug. 21, 2005, available at http://www.nytimes.com/2005/08/21/business/21vioxx.html. For an example of pharmaceutical companies sharing information in order to reduce costs and speed innovation by developing an open data base for researchers in the field of Alzheimer's disease, see Melly Alazraki, Drugmakers Agree to Share Alzheimer's Research Data in Search of Breakthrough, DAILY FINANCE (June 13, 2010, 3:00 PM), http://www. dailyfinance.com/story/drugmakers-agree-to-share-alzheimers-research-data/19513109/. 
when failure to publicize negative results leads to expensive duplication of research that has already proved to be a dead-end. Finally, any costs which impact profit, such as spending development funds on dead-ends, reduce the earnings available to shareholders of the pharmaceutical companies doing the research. ${ }^{135}$

\section{MOVEMENT OF CliniCAL TRIALS OVERSEAS}

Although there are guidelines for conducting human subject research, there is no global, legally binding authority to make sure that they, or any other standards, are followed. ${ }^{136}$ Instead, human subject research is regulated within the country where it takes place unless the country has voluntarily agreed to follow the standards of an international organization such as the World Health Organization (WHO) ${ }^{137}$ or Council of International Organizations of Medical Sciences (CIOMS). ${ }^{138}$

As one commentator notes, "[t]oday, the greatest obstacle to ensuring the health and safety of participants in overseas trials may be the lack of regulation over the [independent contractors] employed by Western pharmaceutical manufacturers. Developing, unstable countries are generally illequipped to oversee, much less manage, the clinical trials being held within their borders." 139 What makes matters worse is that even countries that have their own laws may not be able to enforce them. ${ }^{140}$

135. Ethicist Dr. Haavi Morrein emphasizes in her work that it is misleading to conflate the role of the researcher when the subject is a healthy volunteer versus a usually very ill patient. Haavi Morreim, The Clinical Investigator As Fiduciary: Discarding A Misguided Idea, 33 J. L. MED. \& ETHICS 586, 594 (2005) ("When research involves healthy, normal volunteers who are capable of looking out for their own interests, the major constraint will be to provide full and honest information, and to ensure risks are acceptable. However, where ill persons seeking help are involved, those duties might be enriched to require special vigilance.").

136. Katherine Drabiak-Syed, State Codification of Federal Regulatory Ambiguities in Biobanking and Genetic Research, 30 J. LEGAL MED. 299, 319-20 (2009) (describing, in the context of genetic research, the gaps between international standards for human subject research and Federal, State and International law).

137. The organization Wikileaks reported in December of 2009 that representatives of the world's largest pharmaceutical companies had advance access to a WHO working group report intending to impose restrictions on pharmaceutical company practices. Kaitlin Mara, Big Pharma Caught Spying on the WHO, WIKILEAKs, http://wikileaks.org/ wiki/Big_Pharma_caught_spying_on_the_WHO (last visited Aug. 9, 2010).

138. About Us, COUNCIL FOR INT'L ORGS. OF MED. SCI., http://www.cioms.ch/ about/frame_about.htm (last visited Dec. 17, 2011).

139. Yevgenia Shtilman, Pharmaceutical Drug Testing in the Former Soviet Union: Contract Research Organizations as Broker-Dealers in an Emerging Testing Ground for America's Big Pharma, 29 B.C. THIRD WORLD L.J. 425, 436 (2009).

140. Clinical Research Organizations are stand-alone private companies which conduct clinical trials in the United States and overseas. FDB NETwORK, http://www. fdbnetwork.com/Clinical-Research-Org-CRO (last visited Nov. 14, 2011). They are also described as Contract Research Organizations. Biomedical Research Directory, BIORES.ORG, $\mathrm{http} / / / \mathrm{www}$. biores.org/dir/Companies/Contract_Research_Organizations/ (last visited Nov. 
Because there is no positive international law mandating that private companies running clinical trials (Clinical Research Organizations) comply with the relevant domestic laws of the clinical studies' sponsors, the resulting "regulatory vacuum" makes it difficult for these countries to ensure the welfare of trial participants and forces them to rely on foreign data and foreign review processes. ${ }^{141}$

Because so much research is now done overseas by American companies and by companies intending to develop products for sale in the United States, there have been many recent proposals to extend U.S. human subject protections to overseas drug trials. There are many reasons why pharmaceutical companies are moving clinical trials outside the United States. ${ }^{142}$ For most pharmaceutical companies, it is an issue of cost and convenience; they are exporting research trials overseas for the same reason sneaker companies are moving factories to Asia. ${ }^{143}$ While statistics vary by country, today, the large pharmaceutical companies conduct between fifty and seventy percent of Phase One and Two clinical trials outside of the United States. $^{144}$ Although Congress has given statutory authority to the FDA to regulate and inspect drug manufacturing facilities overseas, it does not have authority to oversee drug trials occurring outside the United States. ${ }^{145}$

If a drug is developed and tested entirely outside the United States, its manufacturing company need never file an IND with the FDA and instead files directly for approval. The FDA clinical data is obtained entirely overseas and therefore never falls under FDA supervision. The FDA does not require a sponsor presenting such an application to prove that its clinical

\section{4, 2011).}

141. Shtilman, supra note 141 , at 436.

142. See generally Adriana Petryna, When Experiments Travel: Clinical Trials AND THE GLOBAL SEARCH FOR HUMAN SUBJECTS (2009) (studying the activities of "Acrossthe-Globe-Research" (AGR), a private company created to facilitate drug trials for pharmaceutical companies).

143. See generally Finnuala Kelleher, The Pharmaceutical Industry's Responsibility for Protecting Human Subjects of Clinical Trials in Developing Nations, 38 CoLUM. J.L. \& SOC. PROBS. 67 (2004) (reviewing international standards for human subject research).

144. See PETRYNA, supra note 144 , at 13.

145. See E. M. Abler, Plugging the GATTS and WTOs: Toward a Globalized Pharmaceutical Regulatory Framework, 29(1) BIOTECHNOLOGY L. REP. 3, 12 (2010) (arguing that the FDA has the authority to negotiate international agreements and to inspect overseas drug manufacturing plants but has not done so effectively because of lack of enforcement resources); see also 21 U.S.C.A. $\S 381$ (2011) (empowering the Secretary of Health and Human Services and, by extension, the FDA to enforce the same regulatory standards on prescription drug imports as on domestically produced prescription drugs); FDA DIV. OF FIELD INVESTIGATIONS, GUIDE TO INTERNATIONAL INSPECTIONS AND TRAVEL, $§ 302.1$ (2002), available at http://www.fda.gov/ICECI/Inspections/ForeignInspections/ucm1 13565.htm\# 303.1 ("The intent of the international inspection program is to ensure that products manufactured in foreign countries meet the same standards of quality, purity, potency, safety, and efficacy as required of domestic manufacturers."). 
trials were conducted under the same regulations as if they had occurred in the United States. Instead the company must file Good Clinical Practice (GCP) guidelines. ${ }^{146}$ This raises concerns about the extent to which the human subjects were provided with informed consent and had adequate protection against injury.

There may be some potential for subjects in studies, which occur overseas, to seek redress in the United States. The Second Circuit recently upheld the right of Nigerian children, who were harmed in a study of the antibiotic Trovan, to sue for a study funded by Pfizer and conducted in Nigeria. ${ }^{147}$ Reversing the district court's dismissal of the case on the grounds of forum non conveniens, the Second Circuit upheld the right of subjects harmed by American companies in the course of human subject research conducted overseas to seek redress in the United States under the Alien Tort Claims Act. ${ }^{148}$

Despite the efforts of several organizations, including the FDA and the World Health Organization, to track on-going clinical trials taking place outside the United States, it is difficult to determine exactly how many of these trials are taking place overseas. The World Health Organization maintains a voluntary International Clinical Trials Registry Platform (ICTRP), which it describes as "a voluntary platform to link clinical trials registers in order to ensure a single point of access and the unambiguous

146. The Code of Federal Regulations provides that, "An application based solely on foreign clinical data meeting U.S. criteria for marketing approval may be approved if: (1) The foreign data are applicable to the U.S. population and U.S. medical practice; (2) the studies have been performed by clinical investigators of recognized competence; and (3) the data may be considered valid without the need for an on-site inspection by FDA or, if FDA considers such an inspection to be necessary, FDA is able to validate the data through an onsite inspection or other appropriate means. Failure of an application to meet any of these criteria will result in the application not being approvable based on the foreign data alone. FDA will apply this policy in a flexible manner according to the nature of the drug and the data being considered." 21 C.F.R. $\$ 314.106$ (2011).

147. For a chronology of these events, see Case Profile: Pfizer Lawsuit (re Nigeria), Bus. \& HUM. RTS. RESOURCE CENTRE, http://www.business-humanrights.org/Categories/ Lawlawsuits/Lawsuitsregulatoryaction/LawsuitsSelectedcases/PfizerlawsuitreNigeria (last visited Nov. 21, 2011). One of the pieces of information discovered from a Wikileaks release is that Pfizer tried to discredit the Nigerian Attorney General in an attempt to make him drop the lawsuit. Pfizer denies this ever happened. There may be some improvement in the ability of subjects in overseas studies to seek redress in the United States. The Second Circuit recently upheld the rights of Nigerian children who were harmed in a study funded by Pfizer. Duff Wilson, Secret Cable Discusses Pfizer's Actions in Nigeria Case, N.Y. TIMES (Dec. 10, 2010), http://www.nytimes.com/2010/12/11/business/11 pfizer.html (last visited Dec. 31,2010$)$.

148. The U.S. Supreme Court rejected Pfizer's petition for certiorari, Adamu v. Pfizer, Inc., 399 F. Supp. 2d 495 (S.D.N.Y. 2005), rev'd sub nom. Abdullahi v. Pfizer, Inc., 562 F.3d 163 (2d Cir. 2009), cert. denied, 130 S. Ct. 3541 (2010), and Pfizer has subsequently settled both lawsuits for a reported $\$ 75$ million. Case Profile: Pfizer Lawsuit (re Nigeria), BUS. \& HUM. RTS. RESOURCE CENTRE, http://www.business-humanrights.org/Categories/Law lawsuits/Lawsuitsregulatoryaction/LawsuitsSelectedcases/PfizerlawsuitreNigeria (last updated Feb. 21, 2012). 
identification of trials with a view to enhancing access to information by patients, families, patient groups and others." ${ }^{149}$ It explains that the reason for having a registry is because:

When researchers embark on a clinical trial, they make a commitment to conduct the trial and to report the findings in accordance with basic ethical principles. This includes preserving the accuracy of the results and making both positive and negative results publicly available. However, a significant proportion of healthcare research remains unpublished and, even when it is published, some researchers do not make all of their results available. Selective reporting, regardless of the reason for it, leads to an incomplete and potentially biased view of the trial and its results. $^{150}$

\section{A. The Relationship Between Big PHARMA ${ }^{151}$ and Academic Medical Cen- ters}

Most consumers of medical research are unaware of the extent to which much of the research conducted at academic medical centers is actually sponsored by private pharmaceutical companies. Today, a research study that is described as originating from Johns Hopkins or Harvard may well have been funded, designed, and implemented by the company marketing the resulting drug or device. Although the early stages of drug testing, in which the subjects are healthy volunteers, are still primarily conducted

149. WORLD HEALTH ORG., About the WHO ICTRP, http://www.who.int/ictrp/ about/en/ (last visited Nov. 21, 2011). See generally Carolyne R. Hathaway et al., The Web of Clinical Trial Registration Obligations: Have Foreign Clinical Trials Been Caught?, 64 FOOD \& DRUG L.J. 261 (concluding that companies need to comply with many different U.S. and international regulations when conducting a clinical trial overseas).

150. WORLD HEALTH ORG., Reporting of Findings of Clinical Trials, http://www. who.int/ictrp/results/en/ (last visited Nov. 21, 2011).

151. "Big Pharma" is a frequently used collective term for the major pharmaceutical companies. Ronald J. Gilson et al., Braiding: The Interaction of Formal and Informal Contracting in Theory, Practice, and Doctrine, 110 CoLUM. L. REv. 137, 1405 (2010) ("The pharmaceutical collaboration and licensing agreement between a 'small pharma,' Pharmacopeia (Pharma), and a 'big pharma,' Bristol-Myers Squibb (BMS), illustrates the essentials of braiding."). See also Katelyn Bernier, Obviating the Obvious? An Appraisal of Pharmaceutical Patents, 10 J. HIGH TECH. L. 208, 208 (2010) ("This note addresses the extent of the market for pharmaceutical research and development in the United States and how pharmaceutical companies have evolved to meet this demand. It also explains the notable relationship that has developed between the major pharmaceutical companies, collectively known as 'Big Pharma,' including, but not limited to, major corporations such as Pfizer Inc., Johnson \& Johnson, and Bristol-Myers Squib, and their generic drug manufacturing competitors like Mylan Inc., Teva Pharmaceutical Industries Ltd. (Teva), and Sandoz."). 
by pharmaceutical companies, it is fair to say that any study involving a subject who is already ill is overseen both by employees of pharmaceutical companies and by doctors who work for or are associated with the hospitals which both provide treatment and serve as a site for research.

The Pharmaceutical Industry ("Big Pharma") has the highest profits of any sector in the U.S. economy. Because these companies fund the clinical trials, they wield a substantial influence over how clinical trials are conducted and how the results are analyzed and distributed. ${ }^{152}$ This is because once a drug is developed, it costs very little to manufacture.

It is the very profitability of the industry that makes it such a powerful force. ${ }^{153}$ Today academic medical centers at many universities are as dependent on pharmaceutical companies as they had ever been on the government. The federal government tends to cluster its research dollars in a small number of institutions. For example, Johns Hopkins receives eighty percent of all the funds NIH grants for medical research. ${ }^{154}$ While there has always been a close relationship between the physicians who ran clinical drug trials in their hospitals and the companies who sponsored them, drug companies are increasingly becoming intertwined with the actual operation of these institutions. The Institute of Medicine reports that a "2006 national survey of department chairs in medical schools and large independent teaching hospitals found that 67 percent of academic departments (as ad-

152. Cong. Budget Office, Research and Development in the Pharmaceutical INDUSTRY (Oct. 2006) 27-28, available at http://www.cbo.gov/ftpdocs/76xx/doc7615/10-02DrugR-D.pdf (Harvard Economics Professor Greg Mankiw explains this is because "[t]he industry's high R\&D spending and relatively low manufacturing costs create a cost structure similar to that of, for example, the software industry. Both industries have high fixed costs (for research and development) and low variable costs (to put a software application onto a CD-ROM or to produce a bottle of prescription medication). Consequently, prices in those industries are usually much higher than the cost of providing an additional unit of the product, because revenue from sales of the product must ultimately cover those fixed costs."). See Greg Mankiw, CBO on Pharma Profits, Greg Mankiw's Blog (Oct. 2, 2006), http://gregmankiw.blogspot.com/2006/10/cbo-on-pharma-profits.html.

153. While private companies must seek the FDA's approval, this oversight comes only in retrospect and only on materials provided to the FDA by the company itself. As a result, an unsuccessful trial in which people were in fact injured or even died may never be known if the company chooses not to bring the drug forward for approval. Drugs tested at private facilities in the U.S. or, increasingly, overseas are tested with no outside oversight of the process. Once a drug is approved, pharmaceutical companies are allowed to engage in marketing practices which are illegal in most other (developed) nations.

154. See generally Caroline McGeough, The Research Industrial Complex: Is unbiased research economically feasible?, THE CHRONICLE (Apr. 22, 2010), http://dukechronicle.com/ article/research-industrial-complex ("In one tower of a nondescript, nine-story white building on Fulton Street, just across from Duke University Hospital, operates the world's largest academic clinical research institute, generating more than $\$ 125$ million in revenue per year from the research grants and contracts it receives from both government sources and from industry. Its more than 218 clients in the pharmaceutical and medical device sectors include corporate giants Johnson \& Johnson, Pfizer, GlaxoSmithKline and GE Healthcare. The Duke Clinical Research Institute, composed of more than 1,000 employees supporting the worldwide clinical research projects directed by 220 Duke faculty.”). 
ministrative units) had relationships with [the pharmaceutical] industry .... [, and] [a]mong the department chairs, 60 percent had [personal] relationships with [the pharmaceutical] industry." 155

While the federal government's investment in research at universities is still greater than the private industry, pharmaceutical companies are catching up as major sources of funding. ${ }^{156}$ There are several reasons why pharmaceutical companies have come to have such a close relationship with universities. In part, their reasons are the same as the government; universities and their medical centers that have the best resources to conduct clinical trials. Pharmaceutical companies today see the same advantages the federal government saw during World War II. Funding research at universities, rather than running their own tests, included the added benefit of using the universities' existing infra-structure and their access to patients. While early testing on healthy human subjects can occur at stand-alone facilities owned and operated by the pharmaceutical companies, when drugs need to be tested on sick people, the companies need to go to hospitals. ${ }^{157}$

But, the pharmaceutical companies' interest in the universities goes beyond the need for human subjects. Largely, universities have become federally subsidized think-tanks where scientists conduct research on which future products can be developed. In addition, the pharmaceutical companies benefit from the prestige doctors in academe who can promote their products by putting their names on articles or serving as speakers. ${ }^{158}$ Final-

155. INSTITUTE OF MEDICINE OF THE NATIONAL ACADEMIES, CONFLiCT OF INTEREST IN MedicAl RESEARCH, EdUCATION, AND PRACTICE 101 (2009).

156. Jeffrey Brainard, The Top 100 Universities in Research Spending Had More Industry Help in 2009, CHRONICLE OF HIGHER EDUCATION (Sept. 28, 2010), http://chronicle.com/article/The-Top-100-Universities-in/124630/?sid=at\&utm_source=at\& utm_medium=en. See also PAUl M. SWAMIDASS, AsSOCIATION OF UNIVERSITY TECHNOLOGY MANAGERS LICENSING ACTIVITY SURVEY (2008), http://www.kauffman.org/uploadedFiles/ ResearchAndPolicy/EntrepreneurshipData/2008data/association-of-university-technologymanagers.pdf (citing Press Release, Association of University Technology Managers, 2007 AUTM Licensing Survey Shows a Statistical Progress Report in Academic Technology Transfer, available at http://www.autm.net/FY_2007_Licensing_Activity_Survey.htm (noting that in 2007, the industry sponsored 3.4 billion dollars of research in universities)).

157. The pharmaceutical companies' relationship with hospitals extends far beyond those associated with academic medical centers. Drug trials are going on in almost every hospital in the country. See Protecting Human Research Subjects: Statement Before the Subcomm. on Public Health and Senate Committee on Health, Education, Labor, and Pensions, 106th Cong. (2000) (statement of William A. Raub, Deputy Assistant Secretary for Science Policy, Department of Health and Human Services), available at http://www.fda.gov/NewsEvents/Testimony/ucm114941.htm.

158. Many critics believe the risk to the university's prestige and credibility is not worth the funding from pharmaceutical companies. See Bryan A. Liang \& Tim Mackey, Confronting Conflict: Addressing Institutional Conflicts Of Interest In Academic Medical Centers, 36 AM. J. L. \& MED. 136, 138 (2010) ("Industry involvement and support of AMCs [Academic Medical Centers] may nevertheless be acceptable if conducted in an appropriate manner. However, industry relationships with AMCs that give rise to conflicts of interest pose a significant concern and challenge to AMCs. Those relationships have the potential to compromise the integrity of an institution and undermine the public's trust in the medical 
ly, the pharmaceutical companies benefit when research they fund results in changes to clinical practice, which draws in more potential consumers for the products they already sell.

Another factor in building the relationship between academic medicine and the pharmaceutical companies is the existing close ties between physicians and the pharmaceutical companies. ${ }^{159}$ Writing in the New England Journal of Medicine, Dr. David Blumenthal reviews the effect of this marketing on practicing physicians citing studies which "found that a wide variety of interactions - meetings with company representatives; the receipt of gifts, free drug samples, and free meals; company support for travel to and lodging at educational events; attendance at lectures by representatives of pharmaceutical companies; acceptance of honoraria; and other relationships-were associated with changes in physicians' use of medications., 160 But the kind of influence considered in this article takes place not in individual doctors' offices but in the academic medical centers where they do research and teach. ${ }^{161}$

Considering the issue in a 2009 report, the Institute of Medicine stated,

It is critical that the public trust that research institutions are protecting the integrity of the medical research on which clinical practice and education depend. Such protection is especially important in clinical research because bias in the design, conduct, or reporting of the findings of such research may expose human participants to risks . . . and may ulti-

and research community.").

159. David Blumenthal, Doctors and Drug Companies, 351 New ENG. J. MED. 1885 (2004), available at $\mathrm{http} / / / \mathrm{www} . n$ jm.org/doi/full/10.1056/NEJMhpr042734 ("[I]nteractions between drug companies and doctors are pervasive. Relationships begin in medical school, continue during residency training, and persist throughout physicians' careers. The pervasiveness of these interactions results in part from a huge investment by the pharmaceutical industry in marketing [directly to doctors].").

160. Id.

161. The extent of the industry's direct involvement in academic medicine has raised concerns significant concern. Many commentators have criticized this practice, both in terms of disclosure and in terms of the effect outside funding has on the integrity of individual researchers. Thomas Stossel is one of these highly critical medical school professors. He writes,

$[\mathrm{R}]$ esearch is not done for free. To fund their work, university investigators obey the whims of nonprofit as well as commercial sponsors. University and governmental rules that prevent wide-ranging interactions between academic researchers and industry limit creative and economic opportunities and are a far greater violation of academic freedom than any documented interference by industry.

Thomas P. Stossel, Regulating Academic-Industrial Research Relationships-Solving Problems or Stifling Progress?, 353 NEw ENG. J. MED. 1060, 1063 (2005). See also Janet L. Dolgin, Debating Conflicts: Medicine, Commerce, and Contrasting Ethical Orders, 35 HOFSTRA L. REV. 705, 724 n.110 (2006). 
mately expose much larger numbers of patients to ineffective or unsafe clinical care. ${ }^{162}$

\section{Evidence of Academic Medicine's Financial Entanglement with} Big Pharma: Ghost Writing and Secret Payments to Medical Academics

Research that changes the standard of practice rather than produces a new drug can also create serious dangers. The most serious allegations were made by the Senate Committee on Finance, chaired by Iowa's Senator Charles Grassley, against both medical researchers and pharmaceutical companies, that the companies secretly-funded research intending to change standards of care.

When clinical care guidelines are changed based on the findings of a study published in a respected peer-reviewed journal, doctors begin prescribing medication for patients who previously would not have been taking anything. A 2009 article in the Boston Globe reported that "[v]irtually all the psychiatrists who wrote the latest clinical guidelines for how to treat depression, bipolar disorder, and schizophrenia had financial ties to drug companies."163 Similarly, the New England Journal of Medicine cites research suggesting that "[a]s many as 59 percent of the authors of clinical guidelines endorsed by many professional associations have had financial relationships with companies whose drugs might be affected by those guidelines." "164

Ghostwriting is the practice of researchers accepting payments from pharmaceutical companies to allow the use of their names as authors on articles they did not write. ${ }^{165}$ Ghostwriting is a particularly dangerous example of how conflicts of interest harm the public's interest. There is no regulation of the peer review journal system through which practicing physicians (clinicians) learn of recommendations to change their treatment plans based on new evidence from what they believe to be disinterested scientific studies. By influencing the result of a study which changes the prescribing practices of thousands of physicians, pharmaceutical companies can greatly expand the sale of drugs already on the market. ${ }^{166}$ A series of

162. Conflict of Interest in Medical Research, Education, and Practice 117 (Bernard Lo \& Marilyn J. Field eds., 2009).

163. Carey Goldberg, Firms Tied to Some MDs Who Set Policy, Boston Globe (Apr. 2, 2009), http://www.boston.com/news/local/massachusetts/articles/2009/04/02/firms_tied_to some_mds_who_set_policy/. (2004)

164. David Blumenthal, Doctors and Drug Companies, 351 New Eng. J. Med. 1885

165. See Staff of S. Comm. On Fin., 111th Cong., Minority Staff Rep. on Ghostwriting in Medical Literature (Comm. Print 2010) (Sen. Charles E. Grassley, Ranking Member), available at $\mathrm{http} / / \mathrm{www}$.grassley.senate.gov/about/upload/Senator-Grassley-Report.pdf.

166. For an account of how hormone therapy became first the standard of care for postmenopausal women to prevent breast cancer, heart disease, and osteoporosis and was then discredited as actually increasing the rates of these diseases, see CARL ELLIOTT, WHITE COAT, 
articles in the New York Times revealed that several of the largest pharmaceutical companies had been paying prominent medical academics to put their names on studies whose results they had not themselves analyzed. ${ }^{167}$ Although this practice is described as "ghostwriting," it is no mere matter of polishing grammar and style. Rather, the pharmaceutical company, not the author with academic medical credentials, conducts the analysis of the data acquired at many different clinical trial sites and draws the conclusions which form the basis for the article. ${ }^{168}$

Announcing a $\$ 56$ million multi-state settlement over its deceptive practices in keeping the dangers of Vioxx from the public, Pennsylvania's Attorney General noted that Merck would no longer engage in ghostwriting, explaining that "[g]hostwriting can be a particularly deceptive practice. Some of these articles looked as though they were being published by an independent doctor or organization, but they were allegedly written by people who worked for, or had some sort of interest, in Merck." 169

One of the barriers to regulating the safety of people involved in clinical drug trials is that these trials are paid for and conducted by private drug companies. U.S. law gives drug companies a lengthy monopoly on the sale of new products in order to justify the cost of research and development. This protection of intellectual property is a wise inducement to create and explore, and our "innovation economy" depends upon sufficient protection of intellectual capital. What Americans should demand in return for this protection is that the FDA be able to make an honest evaluation of the efficacy of drugs. ${ }^{170}$ The majority of studies intended to produce a drug for human use are funded by the pharmaceutical companies that will directly benefit from the drug's sale. ${ }^{171}$

Federal law requires that every institution receiving federal funding for human subject research screen each proposal to assure the safety of the participants. This is done through an Internal Review Board (IRB) made up of both employees of the institution and representatives of outside interests. ${ }^{172}$ The IRB reviews every single application for research and monitors

BLACK HAT: AdVENTURES ON THE DARK SIDE OF MEDICINE 81-84 (2010).

167. Natasha Singer, Medical Papers by Ghostwriters Pushed Therapy, N.Y. TimEs, Aug. 4, 2009, at A1, available at http://www.nytimes.com/2009/08/05/health/research/ 05 ghost.html.

168. Id. ("The court documents provide a detailed paper trail showing how Wyeth contracted with a medical communications company to outline articles, draft them and then solicit top physicians to sign their names, even though many of the doctors contributed little or no writing.").

169. Press Release, Office of Pa. Att'y Gen., Attorney General Corbett Announces a Multi-State, \$58 Million Settlement with Merck over Deceptive Advertising Concerning the Safety of Vioxx (May 20, 2008), available at http://www.attorneygeneral.gov/press. aspx?id $=3660$.

170. Spitzer, supra note 4.

171. At least thirty percent of human subject research studies in the United States are not regulated by the federal or state government. See MARCIA ANGELL, THE TRUTH ABOUT THE DRUG COMPANIES: HOW THEY DECEIVE Us AND WHAT TO Do ABOUT IT 75 (2004).

172. 45 C.F.R. $\S 46.107$ (2011) (regulations governing the composition of IRBs). 
the research by requiring submission of adverse events reports should a subject be harmed. ${ }^{173}$ Too much scrutiny by an IRB may result in a pharmaceutical company moving its trials to a more cooperative venue. Therefore, the temptation to put profit before safety by not alienating funding sponsors is intense. ${ }^{174}$

Writing about the pressures to over-state positive results and suppress negative research results, Professor Rebecca Dresser identifies "[t]ruthful disclosure" "175 as "a fundamental moral principle for scientists." "She identifies "[t]he moral principle of respect for persons" as "under[lying] professional responsibilities to communicate truthfully about research." However, this principle is challenged when those funding the research seek to suppress or mischaracterize information. In describing the intangible harms of research, law professor Richard Saver states that failure to disclose research results does more than harm the public at large; it causes harm to the subjects themselves because it deprives them of "a reasonable expectation ... that the experiment they participate in will contribute to improving the state of medical knowledge." ${ }^{178} \mathrm{He}$ argues that suppressing the results is "an affront to the subject's human dignity"179 because "withholding of trial data treats subjects no better than discarded specimens of a botched experiment." 180

\section{B. Post-market Protection: Dangers to Consumers After a Drug is Ap- proved}

Once a drug is approved for sale in the United States, it is the task of the company which developed and manufactured it to go out and sell it to the only people who can make it available to patients: physicians. While the FDA has statutory authority to oversee the safety of drugs once they are on the market, its efforts are primarily targeted at inspecting the manufac-

173. See Continuing Review After Study Approval Information Sheet: Guidance for Institutional Review Boards and Clinical Investigators, FDA.gov, http://www.fda.gov/ RegulatoryInformation/Guidances/ucm 126424.htm (last updated Oct. 18, 2010).

174. See generally Simon de Lusignan et al., The Roles of Policy and Professionalism in the Protection of Processed Clinical Data: A Literature Review, 76 INT'L J. MED. INFORMATICS 261 (2007); Leonard H. Glantz, Nontherapeutic Research with Children: Grimes $v$ Kennedy Krieger Institute, 92 AM. J. PUB. HEALTH 1070 (2002); Mastroianni \& Kahn, supra note 87, at 1073; Jacqueline Sayers, Clinical Trial Registries: A Survey of Patient Advocate Group Perceptions, 43 DRUG INFO. J. 195 (2007).

175. Rebecca Dresser, When Science Offers Salvation, PATIENT AdVOCACY \& RESEARCH ETHICS 139 (2001).

176. Id.

177. Id. at 140 .

178. Richard S. Saver, Medical Research and Intangible Harm, 74 U. CIN. L. REV. 941, 1007 (2006).

179. Id. at 952 .

180. Id. at 1008 . 
turing process, not looking for hidden dangers. ${ }^{181}$ As the system is now, it relies on complaints by physicians and patients, as well as self-reporting by the manufacturer in order to make the public aware of dangers which may emerge after the testing period. Several factors make this a very difficult and inefficient process. First, there is no easily accessible single source for tracking the interactions between an individual patient and the health care system. Because medical care in the United States is not overseen by any central governing body, it can take a long time for a pattern of bad outcomes to be traced back to a particular drug.

\section{Post-market Reporting}

The problem is that while companies are required to report problems to the FDA, those in the best position to know of these problems, doctors, are not required to report them, nor is there any systematic method in place to track patients taking newly approved drugs. ${ }^{182}$ Section $506(\mathrm{~B})$ of the Federal Food, Drug, and Cosmetic Act requires those receiving permission to market a drug in the United States (Sponsors) to make yearly postmarketing reports to the FDA about potential dangers to consumers. ${ }^{183}$ Even though the manufacturers of a drug are under a continuing legal obligation to report known adverse effects which develop after a drug is released, there is no effective way of knowing whether they have done so or not. $^{184}$

Often, when a drug has been submitted for FDA approval, it has been

181. See David A. Kessler \& David C. Vladeck, A Critical Examination of the FDA's Efforts to Preempt Failure-To-Warn Claims, 96 Geo. L.J. 461, 484 (2008) ("There is much work to be done to shore up the agency's ability to detect adverse reactions and to take prompt and effective measures once previously unidentified risks surface.").

182. See Brian L. Strom \& Kenneth L. Melmon, Can Postmarketing Surveillance Help to Effect Optimal Drug Therapy?, 242 JAMA 2420 (1979) ("If used systematically, PMS can substantially improve drug therapy in the United States. This can be accomplished by generating information on drug use and effects otherwise unavailable, by enabling a more efficient drug approval process, and by educating drug prescribers. However, to be successful, any PMS system will need a good deal of input from such prescribers.").

183. The FDA explains these requirements to the public in a FAQ portion of its website. See Postmarket Requirements and Commitments: Frequently Asked Questions (FAQ), Food and Drug Administration, http://www.fda.gov/Drugs/GuidanceComplianceRegulatory Information/Post-marketingPhaseIVCommitments/ucm070766.htm (last visited Nov. 13, 2011) ("Section 130(a) of Title I of the Food and Drug Administration Section 130(a) of Title I of the Food and Drug Administration Modernization Act of 1997 ('the Modernization Act') became law on November 21, 1997, and added section 506B (Reports of Postmarketing Studies) to the Federal Food, Drug, and Cosmetic Act ('the Act') (21 U.S.C. 356b). This provision requires sponsors to report to FDA annually on the progress of postmarketing study commitments and for FDA to make certain information available to the public.").

184. See Jessamyn S. Berniker, Spontaneous Reporting Systems: Achieving Less Spontaneity and More Reporting, LEDA at Harvard Law School, http://leda.law.harvard.edu/ leda/data/363/Berniker.html (last visited Mar. 3, 2012). 
tested for a very short time on very few people. ${ }^{185}$ As a result, little is known about potential dangers from the drug to a large population of patients who may take it for months, years, or decades. The harm this causes was highlighted in a lawsuit filed against GlaxoSmithKlein by the State of New York. While the company did not admit or deny liability, it "agreed to pay $\$ 2.5$ million in damages and publicly disclose information on all clinical studies in the future." 186

The short testing period is troubling when the drug is intended to treat an acute, isolated, medical event, such as an infection or on-going heart attack. The fact is that many of the drugs are intended for sufferers of chronic conditions who may take them for dozens of years. As one critic explains,

[T] he only way to calculate the long-term effects of certain products is to try them out on mass markets. This history teaches that those effects do not manifest themselves all at once in neat packages. Another lesson is that the measurement of these effects depends on many variables, not all of which will be classified and analyzed at the same time. Thus, even sophisticated scientists dealing with a very large group of people may not think, initially, to focus on subclasses of that group as defined by such characteristics as age, which may appear obvious in retrospect. ${ }^{187}$

185. Rebecca Dresser \& Joel Frader, Off-Label Prescribing: A Call For Heightened Professional and Government Oversight, 37 J.L. MED. \& ETHICS 476, 482 (2009) ("The FDA has accepted the results of trials involving as few as eight people as adequate evidence of safety and effectiveness.").

186. For an account of the allegations and what is publically known of the settlement, see Benjamin Falit, The Path To Cheaper And Safer Drugs: Revamping The Pharmaceutical Industry In Light Of Glaxosmithkline's Settlement, 33 J.L. MED. \& ETHICs 174 (2005).

187. Marshall S. Shapo, EXPERIMENTING WITH the Consumer: The Mass Testing OF Risky PRODUCTS ON THE AMERICAN PUBLIC 182-83 (2009). The American Medical Association agrees. Its Council on Ethics and Judicial Affairs ("CEJA") reported that doctors needed to participate in reporting adverse events because,

Although new drugs and devices are not approved for marketing until numerous studies have been completed, premarketing studies cannot guarantee product safety. Such studies are limited by the small numbers of patients involved and by the populations being studied. Rarely are more than 3000 patients involved in preapproval clinical studies of drugs, and rarely do studies last more than 3 years. Any uncommon side effects, delayed effects, or consequences of long-term drug administration would not be observed before the drug is marketed. Additionally, the patient population used in clinical trials does not usually include vulnerable populations such as the elderly, the young, women, those with complicated disease, or those taking other medications. Information about interactions with these special populations, then, will likely not be revealed in premarketing studies but will only become available after the 
After approval, the number grows larger as it encompasses all of the people to whom the drug is eventually prescribed. While many of these drugs $^{188}$ are life sustaining, recent estimates suggest that millions of Americans every year are injured as a result of harm caused directly by a prescription drug. ${ }^{189}$

It is in the drug companies' interest to market a newly approved drug as widely as possible to start recouping the costs of research and development. Moreover, there are strong incentives to encourage physicians to prescribe new drugs for uses beyond those approved by the FDA based on the research data presented by the pharmaceutical company. ${ }^{190}$ The drug is being given to patients to treat conditions beyond those indicated on the FDAapproved label, ${ }^{191}$ off-labeling, but the physician need never certify why any individual patient's condition warrants any particular prescription medication. Once the FDA approves a prescription drug or medical device for sale in the United States, every patient for whom it is prescribed becomes an unwitting and unwilling enrollee in a large-scale, open market human trial. Although manufacturers are required to collect reports of adverse events, doctors are not required to make them. It is common for problems

new product is on the market.

Am. Med. Ass'n, Reporting Adverse Drug and Medical Device Events, 4 FooD \& DRUG L.J. 359 (1994), available at http://www.ama-assn.org/resources/doc/ethics/ ceja_ba93.pdf.

188. The FDA defines a "new drug" as follows: "(1) Any drug (except a new animal drug or an animal feed bearing or containing a new animal drug) the composition of which is such that such drug is not generally recognized, among experts qualified by scientific training and experience to evaluate the safety and effectiveness of drugs, as safe and effective for use under the condition prescribed, recommended, or suggested in the labeling thereof, except that such a drug not so recognized shall not be deemed to be a "new drug" if at any time prior to the enactment of this Act [on June 25, 1938,] it was subject to the Food and Drugs Act of June 30,1906, as amended, and if at such time its labeling contained the same representations concerning the conditions of its use; or (2) any drug (except a new animal drug or an animal feed bearing or containing a new animal drug) the composition of which is such that such drug, as a result of investigations to determine its safety and effectiveness for use under such conditions, has become so recognized, but which has not, otherwise than in such investigations, been used to a material extent or for a material time under such conditions." 21 U.S.C.A. § 321(p) (2011).

189. Katherine Harmon, Prescription Drug Deaths Increase Dramatically, ScI. AM., Apr. 6, 2010, available at http://www.scientificamerican.com/article.cfm?id=prescriptiondrug-deaths (noting a sixty-five percent increase in hospitalizations due to prescription drug overdose, the article explains that this might represent a substantial undercount since "[s]ome prescription drug-related hospitalizations might be classified under other primary categories, and those who abuse the drugs were not always labeled as having been poisoned. Additionally, the researchers explained, many common terms such as overdose, misuse and abuse are not well standardized in hospitals").

There are, of course, many different ways in which the consumption of prescription drugs can cause death, including deliberate abuse, misunderstanding of dosage instructions by the patient, mistakes by the prescribing doctor, and mistakes by pharmacists.

190. See Dresser \& Frader, supra note 188, at 470.

191. Id. at 476 ("In the existing regulatory framework, once the FDA approves a product for marketing, physicians may prescribe it for indications or patient populations not included on the label. They may also prescribe drugs at dosages or using methods of administration not specified on the label."). 
to remain unknown until brought to attention by a lawsuit. Ghostwriting, off-label prescribing, and direct-to-consumer advertising compound these problems.

2. Features of Current System Which Increase Post-approval Damages: How Pharmaceutical Company's Practice of Ghost Writing Affects the Sale and Marketing of Drugs After Approval

Because there are rarely any restrictions on how a physician uses a new drug, there are many opportunities for pharmaceutical companies to increase sales by directly marketing to physicians. This takes many forms. Articles authored by respected academic physicians play an important part in the marketing and sale of drugs. Rather than ask a practicing physician to take their word on the effectiveness of a new drug, pharmaceutical representatives often distribute articles published in peer-reviewed medical journals. Sometimes the articles report the results of studies which suggest changes to clinical practices. Other times they report on new uses for drugs already approved by the FDA for another purpose. As discussed infra, the latter practice would be illegal if it were the drug company itself suggesting an off-label use. ${ }^{192}$

In both cases, the influence these articles have on physicians is due to the fact that they are authored by prestigious, independent experts in the field and have been reviewed by other independent experts before being published by a medical journal. The discovery that these articles were, in fact, often written by the drug companies themselves and presented to the highly compensated academic authors for their signatures has resulted in considerable damage to the trust between physicians and the pharmaceutical companies which they had seen as their friends.

Section IV outlined the financial dependence of academic medicine on the pharmaceutical industry. One aspect of this is the reliance on income from drug trials which is why academic medical centers were eager to host clinical trials and were, therefore, interested in remaining on good terms with their sponsors. The influence is just as strong, however, when the clinical trials are over, and the drug companies are marketing their new drug. This is because the same physicians whose institutions hosted the trials are also in a position to promote a specific product directly through talks given to other doctors and much more broadly by putting their names to articles which change clinical standards and therefore increase the need for a specific drug. This can either be done by visits from pharmaceutical representatives known as detailing or more directly by physicians talking to their peers at pharmaceutical company-sponsored conferences. ${ }^{193}$ The details of

192. Dresser \& Frader, supra note 188 , at 476-77.

193. For a highly critical account of the process in which doctors are influenced by 
the extent of both of these activities have been coming to light through the hearings conducted by the Senate Finance Committee, Chaired by Senator Charles Grassley of Iowa, ${ }^{194}$ who is conducting an on-going investigation of conflicts of interest between physicians and pharmaceutical companies. ${ }^{195}$

To prevent situations in which doctors are directly paid by or hold shares in pharmaceutical industries, the late Senator Edward Kennedy and Senator Grassley proposed the Physician Payments Sunshine Act of 2009 that would "provide for transparency in the relationship between physicians and [applicable] manufacturers" with respect to payments and other transfers of value and physician ownership or investment interests in manufacturers. $^{196}$

pharmaceutical companies and how, in turn, these doctors influence other doctors, see ELLIOTT, supra note 168, at 51-73, 75-108.

194. Committee Assignments, Senator Chuck Grassley of Iowa, http://www.grassley. senate.gov/about/Committee-Assignments.cfm (last visited March 3, 2012).

195. For a description of these conflicts and how they are managed under existing regulations, see Goldner, supra note 92, at 1211.

196. This is especially prevalent in the field of medical devices, where surgeons often own an interest in a device, which they themselves then use in or on their patients. Essentially, they are in the position of both buyer and seller with payment coming, usually, from the federal government through Medicare. Physician Payments Sunshine Act of 2009: Hearing on S. 301 Before the S. Comm. on Fin., 111th Cong. (2009) (statement of Sen. Charles Grassley). While the conflicts of interest that arise in medical research are much discussed, resolving them is a complex task. Law professor and physician William Sage suggests that the problem comes from considering research conflicts of interest in terms of traditional doctor/patient relationships. Instead, he suggests that research be considered an act of societal good and therefore be regulated according to the researcher's obligations to society, not to an individual subject. See William M. Sage, Some Principles Require Principals: Why Banning "Conflicts of Interest" Won't Solve Incentive Problem in Biomedical Research, 85 TEX. L. REV. 1413 (2007).

The Bill did not advance further than referral to the Committee on Finance. Another, far more widespread, form of conflict of interest comes from the financial entanglements of physicians at the most prestigious academic medical centers in the country who are receiving large payments from pharmaceutical companies to endorse and promote use of the sponsor's products.

Senator Grassley's committee found many examples of conflicts of interest. In one case, a professor of psychiatry at Emory University was receiving hundreds of thousands of dollars in speaking fees from GlaxoSmithKline while serving as principal investigator of a \$3.95 million grant to studying new uses for several of their psychiatric drugs, yet reporting only a fraction of it to his employer. This is important because it was Emory's obligation to report these payments to the National Institutes of Health ("NIH"), which was funding the grant, so that the NIH could review applications for renewal with full knowledge of the existing financial relationship between the investigators and the company. The correspondence from the doctor to Emory explains that the university is as beholden to the company as is the individual doctor. He reminds the dean, who has chastised him for not reporting the full amount of payment:

Surely you remember that Smith-Kline Beecham Pharmaceuticals donated an endowed chair to the department and there is some reasonable likelihood that Janssen Pharmaceuticals will do so as well. In addition, Wyeth-Ayerst Pharmaceuticals has funded a Research Career Development Award program in the department, and I have asked both AstraZeneca Pharmaceuticals and Bristol-Meyers [sic] Squibb to do the same. Part of the rationale for their funding our faculty in such a manner would be my service on these boards. 
The message is clear. If Emory insists on the disclosure to the NIH, it may well jeopardize their receipt of future grants. This means not just the individual doctor but the institution itself will suffer serious financial loss.

A whistleblower could serve at least two important functions in these situations. First, he or she could disclose the financial arrangements themselves. Second, given both the investigators and the universities' financial interest in the study, a whistleblower would be even more valuable in disclosing harm to human subjects or lack suppression of negative results.

\section{Off-Label Prescribing}

Another danger comes from the fully legal practice of "off-label" prescribing. Once the FDA approves a drug, any licensed physician can prescribe it to any patient for any condition. 197 The reason for this is the general trust in doctors to act in their patients' best interests. However, as a health policy consultant who runs a blog called "FDA Matters" noted in response to this event, such activity is inevitable. ${ }^{198}$ Noting that salesmen are trained to sell products and that given the "tens of thousands of sales reps [who] have millions of interactions with prescribers, [n]o matter how well trained and cautioned they are ... there will be days when some reps cannot restrain their "inner salesman.",199

A study conducted by Consumer Reports shows that consumers are well aware of the dangers by private meetings between doctors and salesmen. Sixty-nine percent of consumers thought pharmaceutical companies exerted too much influence on physicians' decisions to prescribe particular drugs. $^{200}$ Unfortunately, state laws which attempt to restrict contacts have been struck down as violations of free speech. ${ }^{201}$

This rule also creates a substantial incentive for pharmaceutical com-

See Letter from Charles B. Nemeroff, Reunette W. Harris Professor and Chairman, Emory Univ. Sch. of Med. to Thomas J. Lawley, Dean, Emory Univ. Sch. of Med. (May 22, 2000) (on file with author). See also Marcia Angell, Drug Companies \& Doctors: A Story of Corruption, N.Y. REV. OF BooKs (Jan. 15, 2009), www.nybooks.com/articles/22237?email.

197. Almost all drugs used to treat children have not been tested or approved for pediatric use and are therefore applied "off-label." See Jerome Groopman, The Pediatric Gap: Why Have Most Medications Never been Properly Tested on Kids?, THE NEW YORKER, Jan. 10,2005 , at 32, available at $\mathrm{http}: / / \mathrm{www}$.newyorker.com/archive/2005/01/10/050110fa_fact.

198. Steve Grossman, Off-Label Promotion and Whistleblowing, FDA MATTERS: THE GROSSMAN FDA REPORT (Sept. 9, 2009, 12:27 PM), available at http://www. fdamatters.com/? $\mathrm{p}=479 \mathrm{~S}$.

199. Id.

200. See Steve Mitchell, Consumers say big pharma influence on docs is concerning, CONSUMER REPORTS, (Aug 24, 2010 5:55 AM), http://blogs.consumerreports.org/health/ 2010/08/consumers-say-big-pharma-influence-on-docs-is-concerning-consumer-reportssurvey.html.

201. See Sorrel v. IMS Health Inc., 131 S. Ct. 2653, 2672 (2011) ("Privacy is a concept too integral to the person and a right too essential to freedom to allow its manipulation to support just those ideas the government prefers.") (holding a Vermont statute restricting the sale, disclosure, and use of pharmacy records revealing the prescribing practices of individual doctors to be a violation of First Amendment right to free speech). 
panies to seek increasingly large markets for the drugs they have already spent hundreds of millions of dollars developing and testing. ${ }^{202}$ The danger to the public is that any one of us may find ourselves taking a drug for a condition for which it was never proven safe or effective. ${ }^{203}$

\section{Direct-to-Consumer Advertising}

The United States and New Zealand are two of the few countries which allow pharmaceutical companies to advertise directly to consumers. ${ }^{204}$ Other countries have not permitted it because of concerns that consumer demand would alter physicians' prescribing habits in ways that would be of no benefit to their patients. Due to a strong Washington lobby and a Supreme Court with increasing sympathy for commercial speech, drug companies in the United States are allowed to advertise their products directly to potential consumers, bypassing the doctors and pharmacists. ${ }^{205}$ By the time a patient in the United States arrives at the doctor, she has not

202. Pfizer's payment of $\$ 2.3$ billion to settle civil and criminal suits stemming from claims its pharmaceutical representatives were making about four different drugs demonstrates that sometimes companies get caught. Press Release, U.S. Dep't of Health \& Human Servs., Justice Department Announces Largest Health Care Fraud Settlement in its History: Pfizer To Pay \$2.3 Billion for Fraudulent Marketing (Sept. 2, 2009), available at http://www.hhs.gov/news/press/2009pres/09/20090902a.html.

203. It is this incentive to expand markets for drugs already approved by the FDA which led to Yaz's efforts to finance research showing its pill safe and effective for preventing acne and PMDD. See Duff Wilson \& Natasha Singer, Ghostwriting is Called Rife in Medical Journals, N.Y. TIMES, Sept. 10, 2009, at B5, available at http://www.nytimes.com/ 2009/09/11/business/1 1 ghost.html; Singer, supra note 169; Natasha Singer, Senate Moves to Block Medical Ghost Writing, N.Y. TIMES, Aug. 19, 2009, at B1, available at http:// www.nytimes.com/2009/08/19/health/research/19ethics.html?_r=1\&scp=4\&sq=\&st=nyt.

204. Barbara Mintzes et al., Influence of Direct to Consumer Pharmaceutical Advertising and Patients' Requests on Prescribing Decisions: Two Site Cross Sectional Survey, 324 BRIT. MED. J. 278, 278 (2002) ("Patients' requests for medicines are a powerful driver of prescribing decisions. In most cases physicians prescribed requested medicines but were often ambivalent about the choice of treatment. If physicians prescribe requested drugs despite personal reservations, sales may increase but appropriateness of prescribing may suffer. Concerns about the value of opening up the regulatory environment to permit direct to consumer advertising in the EU and Canada seem well justified."). But see Jeremy A. Greene \& David Herzberg, Hidden in Plain Sight: Marketing Prescription Drugs to Consumers in the Twentieth Century, 100 AM. J. PUB. HEALTH 793 (2010) (pointing out the long history of patent drug marketing in the United States).

205. For a history of direct-to-consumer advertising, see Jaeun Shin \& Sangho Moon, Direct-to-Consumer Prescription Drug Advertising: Concerns and Evidence on Consumers' Benefit, 22 J. CONSUMER MARKETING 397 (2005) (reviewing the literature on how the public perceives direct marketing of prescription drugs and what effect it has on their behavior), available at $\mathrm{http} / / /$ class.classmatandread.net/campaigneval/s2.pdf. See also Victor E. Schwartz et al., Marketing Pharmaceutical Products In The Twenty-First Century: An Analysis Of The Continued Viability Of Traditional Principles Of Law In The Age Of Direct-ToConsumer Advertising, 32 HARV. J.L. \& PUB. POL'Y 333, 344-51 (2009) (reviewing the history of direct-to-consumer advertising and concluding that its existence does not change the legal obligations of doctors and pharmacists to warn of dangers). 
only diagnosed herself with a condition, which ten years ago didn't exist, but has the name of the drug she wants to treat it. ${ }^{206}$ Other doctors complain that the issue isn't so much that consumers shouldn't have a choice between which drugs to take, but that the advertisements create the impression that a specific set of symptoms requires medication. As Dr. Santa, director of the Consumer Reports Health Ratings Center, explained in the context of advertisements for drugs which treat "leaky bladder," the ads "[g]ive you the impression the problem is more serious [than it typically is] and that treatment with drugs should be the first thing you do, when in fact for most of the people who have problems with incontinence it's a mild to moderate problem that almost universally gets better with exercise programs [such as Kegels] or bladder training.,"207

One of the clearest examples of targeted consumer advertising is in birth control pills marketed to teenagers and young adults. "Mouse around to get info on birth control \& cool features," invites the website for Yaz, one of the nation's top selling birth control pills. ${ }^{208}$ Mousing around what looks like a retro city center surrounded by snow-capped mountains reveals opportunities to subscribe to "Yaz Express," which offers "[p]hotos and articles from fashion, fitness, nutrition, and style pros" as well as celeb looks, books, and music. ${ }^{209}$

Not so visually attractive is a link to an eight-page, single-spaced document in small black type setting out the risks and contraindications. ${ }^{210}$ The

206. Absent any restrictions on where they can advertise, drug companies have followed consumers from television to the web and are now building a substantial presence in social networking sites. This has not been limited to lifestyle drugs such as birth control pills. Recently, the FDA chastised Novartis Pharmaceuticals for misleading the public through a widget about its Tasigna, a drug intended to treat leukemia, writing that, "The shared content is misleading because it makes representations about the efficacy of Tasigna but fails to communicate any risk information associated with the use of this drug." Letter from Karen R. Rulli, Ph.D., Acting Group Leader, Division of Drug Marketing, Advertising, and Communications, to Lisa Drucker, PharmD, MBA, Director, Regulatory AffairsOncology, Novartis Pharmaceuticals Corp. (July 2010), available at http://www.fda.gov/ downloads/Drugs/GuidanceCompliaceRegulatoryInformation/EnforcementActivitiesFDA WarningLettersandNoticeofViolationLetterstoPharmaceuticalCompanies/UCM221325.pdf.

207. Kathleen Doheny, Consumer Reports Survey Shows People Frustrated by Drug Costs and Worry About Safety, WEBMD (Aug. 24, 2010), http://www.webmd.com/healthyaging/news/20100824/poll-patients-unhappy-with-rx-drugs.

208. YAZ, http://www.yaz-us.com/ (last visited Aug. 17, 2010) (The diversions of the Yaz website are only available to web surfers in the United States because the United States is one of the few countries which allow direct-to-consumer advertising of prescription drugs.).

209. Id.

210. The full text of the FDA warning letter can be found at Letter from Richard L. Friedman, Director, Division of Manufacturing and Product Quality, to Dr. Franz-Josef Renneke, Site Manager, Bayer HealthCare (Aug. 5, 2009), http://www.fda.gov/ ICECI/EnforcementActions/WarningLetters/ucm182206.htm. See also FDA Sends Warning Letter to Makers of Yaz-Yasmin, U.S. RECALL NEwS (Sept. 17, 2009), http:/ /www.usrecallnews.com/2009/09/fda-sends-warning-letter-to-makers-of-yaz-yasmin.html; FDA Enforcement Reports, U.S. DEP'T. OF HEALTH \& HuMAN SERVS. (Nov. 25, 2009), 
website also doesn't mention the possibility that its product will soon be recalled in the face of 25,000 lawsuits and a possible FDA order. No one signing up for fashion tips or product coupons would have any indication that they are at serious risk of injury or death from blood clots from a product with many available safer alternatives-albeit less compelling advertising. ${ }^{211}$ As prominent bioethicist and University of Pennsylvania professor, Arthur Caplan, explained on the television show 60 Minutes, "If you want to stir up worry in the public, and you've got the advertising dollars to do it, you can turn almost anything into a disease.",212

In the face of these dangers, it is particularly troubling that there is no comprehensive method of protecting American consumers from the dangers inherent in our current system. The next section proposes that such protection be available by providing comprehensive whistleblower protection for individuals who are likely to have the most knowledge about dangers to the public.

\section{WHY IS IT SO DIFFICULT TO GET INSIDE INFORMATION: WHISTLEBLOWER PROTECTION FOR MEDICAL RESEARCHERS}

\section{A. Brief Overview of Whistleblowing: Unknown Risks and Permanent Harm of Whistleblowing}

The practice of employees reporting the wrongdoings of their employers in order to protect the public is commonly described as "whistle blowing," based on a practice in factories in which an employee could stop production by blowing a whistle if he believed there was a problem with the manufacturing process. ${ }^{213}$ The term "whistle blowing" has come to mean someone who discloses information of interest to the public to which he or

http://www.fda.gov/Safety/Recalls/EnforcementReports/ucm192035.htm.

211. Yaz needs to distinguish itself because birth control pills are more alike than they are different. All prevent pregnancy by blocking the hormones which allow an embryo, once conceived, to attach to a woman's uterus and continue to develop. As a result, the embryo dies and is naturally expelled during the next menstrual period. Yet, fifty years after the marketing of the first "Pill," pharmaceutical companies are still spending millions of dollars to distinguish among their products and build brand loyalty by creating distinct identities for products that differ very little in mechanism or effect. A second way Yaz can expand its market base is to include a consumer group of sexually active women seeking to avoid pregnancy. An even more creative third way, is to fund research to identify new syndromes, like PMDD, or clusters of symptoms that had not previously been treated by prescription drugs and create a market for them by, again, direct-to-consumer advertising. Yaz has done this by encouraging the creation of the condition Premenstrual Dysphoric Disorder. See Bayer HealthCare Pharmaceuticals Inc., Yaz: Highlights of Prescribing Information, Mar. 2011, at 4, available at http://berlex.bayerhealthcare.com/html/products/pi/fhc/YAZ_PI.pdf?WT. mc id=www.berlex.com.

212. Howard Wolinsky, Disease Mongering and Drug Marketing, 6 EUR. MoleCULAR BIOLOGICAL REP. 612, 612 (2005), available at http:/www.ncbi.nlm.nih.gov/pmc/articles/ PMC1369125/.

213. Eva E. Tsahuridu \& Wim Vandekerckhove, Organisational Whistleblowing Policies: Making Employees Responsible or Liable?, 82 J. BuS. ETHICS 107, 109 (2008). 
she has access, which the public does not, by virtue of being an insider. ${ }^{214}$ While whistleblowing is beneficial for those who are protected from a harm about which they would otherwise be unaware, it is almost always a negative experience for the whistleblower himself. ${ }^{215}$

Given the lack of protection available for whistleblowers, we might ask the same question as the author of a recent study: "why would anyone in [the situation of a whistleblower] choose to go to public authorities or to their superiors with observations of organizational wrongdoing?"216 After all, she writes,

There is no question that whistleblowers are putting themselves at risk because the person bringing the charge is of lesser authority in the hierarchy of the organization than is the person or persons being charged .... Those above the whistleblower in the organizational hierarchy . . . control the job performance evaluations that the employee/whistleblower will receive, they control the terms and conditions of their work and under employment-at-will circumstances, they control even the capacity of the dissenting employee to remain in their job. ${ }^{217}$

Moreover, even if the whistleblower sues for retaliatory discharge, "the individual incumbents who are responsible for the firing can hire all the attorneys they want from the company (or the public) coffer.",218

Available information on what actually does happen to whistleblowers has to raise the question, why would anyone do it? Even whistleblowers who kept their jobs reported that their careers stalled afterwards, and new employers looked at them with suspicion. ${ }^{219}$ Research suggests that many people who come forward with information simply do not understand the long-term consequences. ${ }^{220}$ Either they believe "that their history of excellent performance in the firm will insulate them from any retaliation" or "[t]hey are generally unaware of the research literature that demonstrates

214. Orly Lobel, Citizenship, Organizational Citizenship, and the Laws of Overlapping Obligations, 97 CAL. L. REV. 433, 461 (2009) ("By definition, a whistleblower is an insider.").

215. See Moberly, supra note 15, at 979 ("[A]lmost all the benefits of whistleblower disclosures go to people other than the whistleblower, while most of the costs fall on the individual whistleblower.").

216. Joyce Rothschild, Freedom of Speech Denied, Dignity Assaulted: What the Whistleblowers Experience in the US, 56 CURRENT SOCIOLOGY 884, 901 (2008).

217. Id. at $900-901$.

218. Id. at 901 .

219. Id. at 890 .

220. Id. at 901 . 
the prevalence of retaliatory findings, and they may simply underestimate that probability [of retaliation], until they are so far committed that they must now wage a war to retrieve their own honor."221 Of even greater concern, she writes, "most whistleblowers I interviewed mistakenly believed that the extant laws and their 'right to free speech' would protect them.,"222

Yet, even after going through the process and learning for themselves how little protection is available, "a sizeable minority of the whistleblowers interviewed-27 percent of the internal whistleblowers and 44 percent of the external whistleblowers - even after taking a pounding for their disclosures, felt that they had been effective in bringing about positive organizational change." ${ }^{, 223}$ This is consistent with Peter Rost's quotation of a study of whistleblowers at St. Elizabeth's Hospital in Washington that concludes, "only 16 percent said that they wouldn't blow the whistle again," despite the negative consequences. ${ }^{224}$

Whistleblower law expert Professor Richard Moberly explains that the main reason so many whistleblowers do experience retaliation is that the law offers "limited protection." 225 One of the most serious limits is the existing laws' inability to address retaliation which does not take the form of an actual dismissal or demotion. ${ }^{226}$ Another scholar described the current state of legal protection for whistleblowers in the United States as "chaos." 227

The life of any whistleblower, regardless of the presence of legal protection, is a difficult one. Writing about the role of whistleblowers in corporate America, Professor Elizabeth Tippett notes the pervasive "stigma" associated with whistleblowing. ${ }^{228}$ She writes that, "[e]ven when whistleblowers are ultimately vindicated, like the pair of NASA engineers who disclosed the technical failures that led to the Challenger disaster, they are often subject to continuing social marginalization by co-workers.,229

Some whistleblowers triumph, like Harry Markopolus, who is credited with trying to blow the whistle on Bernie Madoff; Coleen Rowley who

221. Id.

222. Id.

223. Id. at 892.

224. Peter Rost, The Whistleblower Confessions of a HealthCare Hitman front matter (2006).

225. Moberly, supra note 15 , at 977 .

226. See generally id.

227. DaCosta, supra note 17 , at 957 . These varying legislative and judicial approaches to the adverse employer action element under state and federal laws leave many whistleblowers inadequately protected against retaliation that falls short of termination. A standard that prohibits only actual discharge is most glaringly deficient because it permits an employer to retaliate in any manner, no matter how egregious, short of officially terminating a whistleblower. See also Johnson, supra note 17.

228. Elizabeth C. Tippett, The Promise of Compelled Whistleblowing: What the Corporate Governance Provisions of Sarbanes Oxley Mean for Employment Law, 11 EMPL. RTS. \& EMPLOY. POL'Y J. 1, 3 (2007).

229. Id. at 16. 
warned the FBI before the terrorist attacks on 9-11 of suspicious activities in local flight schools; and Sherron Watkins, who it is said brought down Enron with a single phone call. Such individuals enjoy public approbation and perhaps even lucrative careers as motivational speakers. Time Magazine voted Rowley and Watkins "Person of the Year" for 2002. ${ }^{230}$ However, for every successful whistleblower, there are hundreds more who have suffered significant retaliation. This is true even if the whistleblower does not suffer, what could be defined legally, as adverse consequences including firing or demotion.

Given this grim prognosis, most would wonder why would anyone do it. Yet the research shows that rather than being unsophisticated people unaware of the consequences of their actions, or social misfits who are simply making things difficult for their employers, it turns out that whistleblowers are often the most loyal employees. ${ }^{231}$

\section{B. Whistleblowers' Historical Role in Science and Medicine}

The doctor's oath is to do no harm and the scientist's is to be honest about results. There is a long tradition of whistleblowing in science and medicine by both public and private employees, but it is not one which would provide any comfort to individuals who are considering reporting misconduct. Describing two cases in which medical researchers faced harsh punishments, ethicists Rosalind Rhodes and JJ Strain write:

To effect a change in the current status quo the incentives for addressing problematic behaviour have to be changed. Ethically appropriate reactions to researcher misconduct would be far more likely if whistleblowers could be seen as helpful colleagues and as valued friends of the institution instead of its enemies. We advocate this kind of transformation, not only to address the misdeeds of academic medicine but to create a moral environment for all who have to work in it and learn from it. ${ }^{232}$

Discussing whistleblowing in the healthcare industry, Professor Leslie

230. "Persons of Years Past: Cynthia Cooper, Coleen Rowley and Sherron Watkins," TIME, http://www.time.com/time/specials/packages/article/0,28804,1946375_1947772_ 1947759,00.html (last visited Mar. 27, 2012).

231. Robert A. Larmer, Whistleblowing and Employee Loyalty, 11 J. BUs. ETHICS $125-$ 128 (1992).

232. Rosamund Rhodes \& J.J. Strain, Whistleblowing in Academic Medicine, $10 \mathrm{~J}$. MED. ETHICs 30, 35 (2004); see also Thomas A. Faunce et al., Supporting Whistleblowers in Academic Medicine: Training and Respecting the Courage of Professional Conscience, $10 \mathrm{~J}$. MED. ETHICs 30, 40 (2004). 
Griffin defines whistleblowers as "individuals who report misconduct" and further describes them as "frequently fac[ing] retaliation for doing so.,"233 Many have suggested that the very nature of scientific research, activity taken far outside the view of the public which could cause serious threats to health and safety, imposes an obligation on scientists to be whistleblowers when they perceive danger. ${ }^{234}$ Citing the example of two government scientists who received extensive press coverage as whistleblowers, Griffin writes, "State and federal law's treatment of health care whistleblowers is comprehensive and complex. Wise health lawyers will anticipate the whistleblowers in their midst and establish appropriate programs and procedures to prevent both misconduct and retaliation long before the whistleblower' story appears on CNN."235

Unfortunately, whistleblowers in science and medicine face the same risk of retaliation as those in other industries. There are many examples of scientists who have blown the whistle on what they believed to be either research misconduct or suppressed information about prescription drugs already on the market. Almost all stories end badly. ${ }^{236}$

\section{Researchers in Drug Research are also Bound by Confidentiality} Agreements, which Impose Penalties for Violation of the Company's Trade Secrets

For example, Dr. David Kern was a physician employed by Brown University - he served as a consultant for a company that manufactured flocking material. ${ }^{237}$ Dr. Kern began to notice the presence of a rare lung disease in the workers he treated. He drafted an abstract for a professional

233. Leslie Griffin, Watch Out for Whistleblowers, 33 J. L. MED. \& ETHICs 160, 160 (2005).

234. See generally Thomas A. Faunce \& Susannah Jefferys, Whistleblowing And Scientific Misconduct: Renewing Legal And Virtue Ethics Foundations, 26 J. MED. \& L. 567, 581-82 (2007) (citing lack of general awareness of basic principles of research ethics such as the declaration of Helsinki, the authors suggest that "[i]n a research environment that is blind to its contribution to the greater public good, its own ethical standards and under financial pressure, the role of the whistleblower is even more crucial in uncovering scientific misconduct and preventing it from continuing. Ultimately the scientific research community needs to educate and pay due respect to not only research ethics, but also to remove the fear and shame involved and legitimize whistle blowing and the whistleblowers by instilling in young researchers' character the belief in this greater good or telos."). See also Michael Davis, Some Paradoxes of Whistleblowing, 15 Bus. \& PROF'L ETHICS J. 1, 7 (1996) (developing a theory that whistleblowing is "morally required" for a member of any organization with well founded knowledge that others are threatened by "serious harm" which they would otherwise be unaware, extending this obligation beyond scientists).

235. Griffin, supra note 237 , at 160 .

236. See Interview with Dr. Little, available at http://www.dailymotion.com/ video/xdey8b_kitty-little-whistleblowing-scienti_news (last visited Nov. 21, 2011).

237. For accounts of the events which resulted in Dr. Kern's firing, see Statement from Brown University on Academic Freedom of Dr. David Kern (May 21, 1997), available at http://www.brown.edu/Administration/News_Bureau/1996-97/96-133.html. 
conference, but the company told him that the publication would be disclosing trade secrets, which was in violation of Dr. Kern's contract. ${ }^{238}$ To prevent this problem, Dr. Kern redrafted his abstract to further obscure the identity of the company. At this point, the company contacted Brown University and threatened suit. The university then asked Dr. Kern to withdraw the abstract. He did not and went ahead with publication. ${ }^{239}$ He then faced retaliation by both the company and by Brown University. ${ }^{240}$

While a few scientific whistleblowers occasionally receive large monetary awards, it is likely that they will no longer be able to work in scientific research, the field to which they have devoted extensive years of training. ${ }^{241}$ In a 1995 report on the results of a research study of whistleblowers submitted to the ORI, Dr. Lawrence Rhodes wrote,

Unfortunately, a small but significant proportion of
complainants reported very serious consequences of
their whistleblowing. At least ten percent of com-
plainants reported each of the following: Eight whis-
tleblowers $(12 \%)$ reported being fired, not being
renewed, and/or being denied salary increases, 14 re-
ported losing research support $(21 \%)$, and 7 whistle-

238. Robert R. Kuehn, 30 AM. J.L. \& MED. 333, 335-36 (2004). Although it is reasonable for pharmaceutical companies to want to protect their intellectual property through nondisclosure agreements, those agreements should be used to shield dangers to the public health. Several commentators have noted the harmful effects of these agreements in the specific context of pharmaceutical companies. See Thomas O. MCGarity \& Wendy E.

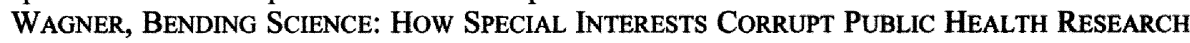
111 (2008) (explaining that "companies can invoke confidentiality clauses in employee contracts" to prevent current and former employees from revealing "secret research"). Professor Jerome Reichman describes these non-disclosure agreements as symptoms of the inherent conflict of interest from a company which stands to profit from marketing a drug to do its own clinical trials. He writes,

A better alternative to calls for mandatory disclosure is to remove the direct link between the test sponsor (the drug company) and the drug testers. One approach would be to establish an independent testing agency to conduct clinical trials under specified conditions of transparency. Unlike the current system, drug companies would no longer directly compensate the scientists evaluating their own products. Instead, the scientists would now work for the testing agency, supported by general funds collected from the pharmaceutical industry.

Jerome Reichman, Rethinking the Role of Clinical Trial Data in International Intellectual Property Law: The Case for a Public Goods Approach, 13 MARQ. INTELL. ProP. L. Rev. 1, 50-51 (2009).

239. Kuehn, supra note 241 , at $335-36$.

240. Id.

241. Becky Maclaine is a biologist who recently recovered $\$ 1.37$ million from Pfizer based on her claim that she was fired for raising concerns about research she was doing for Pfizer on genetically engineered viruses. Maclaine alleged she had been made sick from the virus. Andrew Pollack \& Duff Wilson, A Pfizer Whistle-Blower Is Awarded \$1.4 Million, N.Y. TiMES, Apr. 2, 2010, available at http://www.nytimes.com/2010/04/03/business/ 03pfizer.html. 


\section{blowers $(10 \%)$ reported losing staff support and/or re- ceiving less desirable work assignments. ${ }^{242}$}

Again, it is important to keep in mind that these consequences often happen to the same people. In fact, just twenty whistleblowers are responsible for the seventy consequences reported under the top three headings in the table contained in the 1995 report. $^{243}$

On one hand, these findings refute the notion that every whistleblower suffers substantial negative consequence. On the other hand, they confirm that whistleblowers frequently face the prospect of significant hardship for their efforts. A substantial proportion suffers at least some difficulties as a result of blowing the whistle, and a sizeable group suffers devastating consequences, such as losing their jobs. ${ }^{244}$ Unfortunately, there is little evidence that "appropriate regulations and enforcement procedures" were ever developed as a result of this research, let alone that they reduced retaliation. $^{245}$

\section{WHY EXISTING WHISTLEBLOWER PROTECTION LAWS DON'T WORK}

Existing statutes are of little use in protecting those with knowledge of danger from human subject research because the location and employment status of potential whistleblowers are so broad. Most existing whistleblower statutes privilege employment status as a starting point for offering protection against retaliation. In many cases this is reasonable because the most likely source of retaliator is the specific entity for which the whistleblower works. However, the area of drug development employment status is far too narrow. Because not all who report are employed by the company, they do not face retaliation from their employer. This is especially true in the case of doctors, scientists, and their staffs ("researchers"), ${ }^{246}$ who de-

242. LAWRENCE RHOADES, CONSEQUENCES OF WHISTLEBlowing FOR THE Whistleblower IN MisconduCt IN SCIENCE CASES 17 (1995), available at http:// ori.hhs.gov/documents/consequences.pdf.

243. Id.

244. Id.

245. Id.; Thomas A. Faunce \& Susannah Jefferys, Whistleblowing and Scientific Misconduct: Renewing Legal and Virtue Ethics Foundations, 26 MED. \& L. 567, 576 (2007) ("A timely recent example of this has concerned the US Food and Drug Administration (FDA), where whistleblowers such as Dr[.] David Graham have indicated that FDA scientists have been discouraged by supervisors from raising questions about drug safety and sometimes have been prevented from sharing their concern with FDA advisory committees.").

246. There is no single word which describes all of the people who are likely to be involved in research studies intended to affect medical care. Almost all of the people leading a medical research team are physicians with an M.D. degree and, increasingly, also a Ph.D. in a biomedical field. These doctor/scientists usually hold academic appointments in universities even though their research is usually funded by the federal government or a private foundation or private company. As medical research becomes increasingly complex and expensive, with much research now being done at the level of the genome, physicians con- 
sign and run the clinical trials before, and sometimes after, the drugs go on the market. Despite their important role, researchers who see problems and who express their concerns, even within their own institutions, do so at the risk of their careers and livelihood. ${ }^{247}$ There are model statutes that provide protection based on the content of the information, rather than on employment status. They must be the foundation of any new FDA rule.

The system of law and regulation in the United States to provide protection against retaliation for insiders who know of dangers to the public's health and safety during human subject research or drug development is as fragmented and inconsistent as regulating the research itself. Arguing that the current laws intended to encourage whistleblowing were ineffective, former Supreme Court Justice Souter described the uncoordinated and inconsistent federal and state whistleblowing statutes as inadequate because the protection they provided was "piecemeal," 'patchwork," and "hodgepodge." 248 It is the lack of comprehensive protection over research and over whistleblowers that makes it so easy to hide dangers at every stage of the process.

Another problem is that the existing laws often narrowly describe who

ducting funded research usually also have doctorates in a medical science such as biochemistry. These M.D./Ph.D.s, however, only represent a fraction of those who would have direct involvement in ongoing studies or in the presentation of applications for approval to the FDA. Whether the research is taking place in a university hospital, a private hospital, or a private company's own testing facility, there are likely to be hundreds of people ranging from medical students and nurses to professional study coordinators to pharmacists to hospital cleaning staff who care for the patients/subjects and may have important information about the study. Less visibly, pharmaceutical companies employ health care professionals to oversee and run studies either at academic medical centers or freestanding facilities. Finally, the government itself directly conducts clinical research on the campus of the National Institutes of Health. Any individual at any of these locations may have direct access to information about a research study which presents a direct danger to the public's health or safety. It is because there are so many different people in so many different settings and geographic locations with so many job titles who have access to information that there needs to be protection based on the subject matter of the disclosure.

247. Many commentators have noted the failure of the current system to protect whistleblowers. Writing recently about the case of Suzanne Stratton, who was fired from her job at Carle Foundation Hospital for challenging the general lack of compliance with human subject safety provisions, Jonathan Rackoff noted that although she had been vindicated by the government's regulatory agency, the Office for Human Research Protections ("OHRP"), she was not reinstated. Jonathan Rackoff, Whistle-Blower Protection a Must: Individuals Who Report Ethical Misconduct Unfortunately Often Put Their Jobs on the Line, 30 GEN 1 (2010), available at http://www.genengnews.com/gen-articles/whistle-blower-protection-amust $/ 3187 /$ (last visited Nov. 11, 2011).

248. Griffin, supra note 237, at 160 (citing Miriam A. Cherry, Whistling in the Dark? Corporate Fraud, Whistleblowers, and the Implications of the Sarbanes-Oxley Act for Employment Law, 79 WASH. L. REV. 1029, 1049, 1064 (2004)); Peter R. Marksteiner, The Flying Whistleblower: It's Time for Federal Statutory Protection for Aviation Industry Workers, 25 J. LEGIS. 39, 41-42 (1999) ("Dozens of federal and state statutes and a hodgepodge of common law doctrines provide whistleblower protections for workers who report safety violations in a host of different industries."); Richard E. Moberly, Unfulfilled Expectations: An Empirical Analysis of Why Sarbanes-Oxley Whistleblowers Rarely Win, 49 WM. \& MARY L. REV. 65 (2007); see generally Elletta S. Callahan \& Terry M. Dworkin, The State of State Whistleblower Protection, 38 AM. Bus. L.J. 99 (2000). 
is protected for disclosing various kinds of information. Professor Richard Moberly, an expert in whistleblower law, described research showing that in the existing statutory and common law "[p]rotections consistently fail to redress retaliation against whistleblowers, in large part because whistleblowers fail to fit their claim into the narrowly-drawn boundaries of the law." 249 A system this broken cannot be fixed by a stroke of the pen. Rather, protection of the public must be pursued using several different legal and policy interventions.

\section{A. Lack of Constitutional Protection}

\section{Medical Researchers Are Not Protected by the First Amendment?}

In Garcetti v. Cebalos, the Supreme Court concluded that there is no First Amendment protection for employees of public institutions who disclose information against the wishes of their employers. ${ }^{250}$ Finding that wrongdoing is part of their jobs makes it unlikely that medical researchers employed by public universities would have First Amendment protection from retaliation for disclosing their concerns about dangers to the public's health from a clinical trial or a newly issued prescription drug. ${ }^{251}$ Those who argue Garcetti v. Ceballos has not resulted in any diminution of whistleblower protection for public employees because the plaintiff, $\mathrm{Mr}$. Ce-

249. Moberly, supra note 15, at 977 (proposing that employers be required by law to include anti-retaliations provisions in their codes of conduct); see also Moberly, supra note 252 , at 65 .

250. Garcetti v. Ceballos, 547 U.S. 410 (2006).

251. Id. at 441 (Souter, J., dissenting).

First Amendment protection, if available, would go beyond the whistleblower protections required by the contracts between the university and the NIH. It is not the funding source of the research that is relevant, but rather the employment status of the researcher. Before Garcetti, employees of public universities had at least two sources of protection unavailable to employees doing the same kind of work at private universities. First, public employees may have been protected by the First Amendment "public employee speech" doctrine that had developed through Pickering. Second, employees at public universities had the same whistleblower protection as any other employee of their individual state. There is no question that the Garcetti decision has had a negative effect on public employees who report what they consider wrongdoing within the scope of their own job description.

See, e.g., David L. Hudson, Jr., Commentary: Public-Employee Speech and the Garcetti Effect, GETLEGAL (Sept. 28, 2009), http://public. getlegal.com/articles/garcetti-effect (describing the Garcetti decision as "having a negative impact on the functioning of our democratic government" and stating "that Garcetti creates an additional threshold hurdle that most claimants will have a tough time clearing. As one plaintiff's attorney told me, many of his clients have been 'Garcettized.' After Garcetti, the importance of the information is not relevant. Many employees have spoken out on matters of public concern-even rank corruption in the workplace-but if the speech can be classified as official, job-duty speech they have no First Amendment protection."). 
ballos, was not himself a whistleblower miss the point. ${ }^{252}$ The minority's strongest objection was the chilling effect this decision would have, and it specifically identified the reduced protections for whistleblowers by eliminating any possible extension of First Amendment rights. ${ }^{253}$ Although employees of state universities will still have the state whistleblower protection, these statutes are often narrowly focused on reports about waste fraud and abuse in state government and would not apply to a study funded privately. $^{254}$

The Supreme Court recently reaffirmed the importance of these regulations, writing that "[e]xposing governmental inefficiency and misconduct is a matter of considerable significance" but pointed to a "powerful network of legislative enactments - such as whistle-blower protection laws and labor

252. See Lawrence Rosenthal, The Emerging First Amendment Law of Managerial Prerogative, 77 FoRDHAM L. REV. 33, 56 (2008) (arguing that since "Ceballos learned of the circumstantial evidence suggesting police perjury from the defense counsel . . . not as the result of any information in the exclusive possession of the District Attorney or Sherriff's office," his memo to his superior that the sheriffs were going to offer false testimony was merely an expression of his opinion, not "the disclosure of otherwise suppressed evidence of governmental misconduct.").

253. Garcetti, 547 U.S. at 437-41 (Souter, J., dissenting).

254. For example, a scientist at a state university who felt human subjects were being mistreated or results of a study funded by a pharmaceutical company were being suppressed may well not be covered depending on the wording of her state's whistleblower statute protection against retaliation in a qui tam lawsuit.

If the court finds a whistleblower was terminated or otherwise mistreated for filing a qui tam lawsuit, the employee is entitled to reinstatement at the same seniority level as if he or she had never left the company, two times the amount of back pay owed plus interest, and compensation for any 'special damages' sustained as a result of the discrimination, such as attorneys' fees (see Section 3729 of the False Claims Act).

Taxpayers Against Fraud Education Fund. The False Claims Act Legal Center, Information for Whistleblowers, http://www.taf.org/whistleblower.htm (last visited Aug. 22, 2009); see also Complaint, State of California ex rel. Hunter Laboratories, LLC and Chris Riedel vs. Quest Diagnostics Inc. (No. Civ 450691), available at http://ag.ca.gov/cms_attachments/ press/pdfs/n1705_complaint_asfiled.pdf.

Until the Court's decision in Garcetti, First Amendment Scholars, whose discipline is shaped opinion by opinion, had believed the parameters of First Amendment Protection for the speech of public employees were well outlined by a series of cases which established what was called "the Public Speech Doctrine." The First Amendment Center's legal correspondent Tony Mauro explained that, "[a]fter yesterday's ruling, . . . many ... First Amendment advocates and analysts were left feeling that the high court had departed significantly from its traditional approach to government-employee speech, which included freedom of speech as one of the factors to be balanced in deciding whether an employee's speech should be protected.

Tony Mauro, Head-Scratching Follows Garcetti Ruling, FIRST AMENDMENT CENTER, May 31, 2006, http://www.firstamendmentcenter.org/head-scratching-follows-garcetti-ruling.

The Court distinguished speech that was part of a public employee's job description from the general opinions of a public employee about the activities of the government outside his or her own place of work. Garcetti, 547 U.S. at 417-20. 
codes - available to those who seek to expose wrongdoing."255

However, noting an inconsistency between the Court's holding in Pickering and Garcetti, Justice Souter wrote,

[It] is not a whit less true when an employee's job duties require him to speak about such things: when, for example, a public auditor speaks on his discovery of embezzlement of public funds, when a building inspector makes an obligatory report of an attempt to bribe him, or when a law enforcement officer expressly balks at a superior's order to violate constitutional rights he is sworn to protect. (The majority, however, places all these speakers beyond the reach of First Amendment protection against retaliation. $)^{256}$

Furthermore, despite the existence of both federal and state whistleblower statutes, most people know that disclosing information one's employer chooses to keep secret will likely lead not only to being fired but also to becoming unemployable. The lack of protection for whistleblowers means that those with the best information about dangers to participants in medical research and to the patients, who will eventually use the products developed from, the scientists, researchers, and doctors conducting the experiments and analyzing the data, risk their jobs and their futures if they bring this information to light either within their own company, to government regulators or to the press. ${ }^{257}$

It is as an employee of a public institution that a research scientist would be able to claim protections beyond that available to those employed by private universities or indeed private companies. ${ }^{258}$ Interpreting Garcet-

255. Garcetti, 547 U.S. at 424-26.

256. Id. Neither whistleblowing nor research misconduct are exclusively American Phenomenon. Australia has devoted considerable resources to funding a study of what happens to government whistleblowers in an effort to see whether existing legislation provides enough protection. See generally Tess Livingstone \& Brendan O'Malley, Laws Fail Those Who Speak Up, THE WHISTLE, Nov. 2005, at 3, available at www.bmartin.cc/dissent /contacts/au_wba/whistle200511.pdf (whistleblower at world bank revealed Wolfowitz's financial records http://blogs.wsj.com/washwire/2007/05/15/whistleblower-seeks-change-inworld-bank-governance/); WikiLeaks, http://www.wikileaks.ch/About.html (last visited Aug. 12, 2009) (The website Wikileaks describes its mission "as seeking worldwide justice through strong transparency.").

257. Many commentators have noticed the inconsistency between protection offered to sources who provide information to the press and lack of protection for whistleblowers who make internal reports to their superiors, as Ceballos did; see Jenny Mendelsohn, Calling The Boss Or Calling The Press: A Comparison Of British And American Responses To Internal And External Whistleblowing, 8 WASH. U. GLOBAL STUD. L. REV. 723 (2009) (comparing US and UK laws on internal whistleblowing verses leaking information to the press).

258. The question raised is whether first amendment restrictions on medical researchers employed at public universities are actually restrictions on academic freedom. The short 
$t i$, the Fifth Circuit found that there was no constitutional protection "when a public employee raises complaints or concerns up the chain of command at his workplace about his job duties." 259 Writing four years after Garcetti, however, it is possible to see that Garcetti is already being cited to support ruling against professors engaged in disputes with administrators at public universities. $^{260,261}$

\section{a. Federal whistleblower law provides little protection for federal employees and none for private employees}

There is a long tradition of government employees as whistleblowers in the United States. In a 1991 article describing the role that whistleblow-

answer to that question is "we don't know." The Supreme Court specifically declined to address the issue of academic freedom. The majority opinion rather cryptically states that although Justice Kennedy's majority opinion made clear that it did not see Garcetti as a statement suggesting professors at public universities no longer had the first amendment protection associated with academic freedom, it is hard to imagine that it reserved any such protection for the disclosure of information by employees of public universities-regardless of their status as professors. The Supreme Court deliberately did not elaborate on how its decision in Garcetti would affect academic freedom. Professor Paul Horowitz makes the interesting observation that although the Supreme Court often acts as if the professors at public universities have special status under the First Amendment; it is difficult to pin down where that status is rooted in either the Constitution or later interpretations of it. See Cynthia Estlund, Free Speech Rights That Work At Work: From The First Amendment To Due Process, 54 UCLA L. REV. 1463, 1469 (2007) ("The meaning of Garcetti for teachers and scholars remains unresolved; the Court bracketed those issues as ones in which academic freedom may play a role."); Paul Horowitz, Universities as First Amendment Institutions: Some Easy Answers and Hard Questions, 54 UCLA L. REV. 1497, 1513 (2007) ("Practically speaking, courts have already accepted that universities play a distinct role in our First Amendment firmament. The United States Reports are replete with examples of the Supreme Court extolling the unique, and uniquely important, role played by universities in the accumulation and advancement of knowledge [and in contributing to public debate. To this day, the Court's decisions continue to recognize the special role played by universities in public discourse, and to tread lightly around any suggestion that general rules that are otherwise applicable under standard First Amendment doctrine would apply in the same way in the university context.").

259. Davis v. McKinney, 518 F.3d 304, 313 (5th Cir. 2008).

260. Helen Norton, Constraining Public Employee Speech: Government's Control Of Its Workers' Speech To Protect Its Own Expression, 59 DukE L.J. 1, 12 n.44 (2009) ("Speech on university governance issues, however, may be unprotected after Garcetti even if speech related to scholarship and teaching receives some sort of academic freedom protection.") (citing Renken v. Gregory, 541 F.3d 769, 774 (7th Cir. 2008) (applying Garcetti to conclude that the First Amendment does not protect a tenured professor's complaints about a university's use of grant funds because they were made pursuant to his official duties)); Hong v. Grant, 516 F. Supp. 2d 1158, 1167-68 (C.D. Cal. 2007) (applying Garcetti to conclude that the First Amendment does not protect a professor's critical statements regarding the hiring and promotion of other professors and the use of lecturers because this speech was uttered pursuant to his official duty to participate in university governance)).

261. The strongest argument that Garcetti did not change the extent of First Amendment protection available to public employees but rather clarified its scope is that no previous case interpreting protection of public employees' speech involved a dispute with the speaker's employer over an issue arising in the course of his job. $I d$. 
ers play in the federal government, ${ }^{262}$ Professor Bruce D. Fisher wrote,

Federal whistleblowers have exposed alleged defense contractor accounting improprieties, described possible misconduct and federal prison mismanagement, highlighted mismanagement of federal health care for Native Americans, questioned the administration of the United States' system of justice, and alleged numerous improprieties in the administration of federal agencies. Whistleblowing can occur at high and low levels of the federal government. Whistleblowers can save the federal government-and federal taxpayers-billions of dollars. Whistleblowers can serve as a vital communication link between the middle echelon federal employee, who sees the workings and shortcomings of federal programs on a daily basis, and the policy-makers in Congress. ${ }^{263}$

Yet, the title of Professor Fisher's article, The Whistleblower Protection Act of 1989: A False Hope for Whistleblowers, reflects the fact that despite substantial efforts on the part of Congress to provide a regulatory scheme to protect whistleblowers, they still very much face retaliation and, in many cases, disgrace.

All federal employees, including scientists, are protected under the existing federal whistleblower statute. ${ }^{264}$ However, that act is focused narrowly and weakly enforced. Whatever protection it provides federal employees is inadequate to protect human subjects or consumers of prescription drugs. $^{265}$

In not just health and safety issues but rather in all areas of possible wrong-doing, the federal government has moved beyond a passive posture

262. Bruce D. Fisher, The Whistleblower Protection Act of 1989: A False Hope for Whistleblowers, 43 RUTGERS L. REV. 355, 357 (1991).

263. Id. at 357.

264. Pamela H. Bucy, Information as a Commodity in the Regulatory World, 39 Hous. L. REV. 905 , 951 n.255 (2002).

For example, Grace Pierce, M.D., was demoted from her position as Associate Director of Medical Research at Ortho Pharmaceutical Corp. after she refused to proceed on human trials that both she and her fellow researchers considered carcinogenic .... Although Dr. Pierce's position on the carcinogenic nature of the drug in question was supported by Food and Drug Administration (FDA) guidelines, her supervisor, the Executive Director of Medical Research, 'accused her of irresponsibility, lack of judgment, and conduct unbecoming a director.'

Id. (citation omitted).

265. Garcetti, 547 U.S. at 436-33 (Souter, J. dissenting) (quoting San Diego v. Roe, 543 U.S. 77,82 (2004) (per curium)). 
of relying on laws that protect those who come forward to laws which both provide bounties as an incentive and punishments for not doing so.

\section{b. Characterizing hiding information about a drug as a false claim against the government}

Congress has long seen the need for providing protection to federal employees who learn of fraud, waste, or abuse in government as well as employees of private companies who receive federal money, but this protection does not usually extend to dangers to the public's health and safety. Writing to sixteen of the largest pharmaceutical companies on July 1, 2010, Senator Chuck Grassley of Iowa demanded that they each send his Committee their company's policies on protecting whistleblowers. As he explains in a press release,

The False Claims Act is a proven success in both identifying and deterring fraud and recovering fraudulently obtained taxpayer dollars. The more that can be done to create awareness of it, the more good it can do. My appeal to drug makers is based on the fact that they have a public responsibility to safeguard the tax dollars that pay for their products, and promoting a Congress has long seen the need for providing protection to federal employees who learn of fraud, waste or abuse in government culture where those who speak up about possible fraud are rewarded rather than retaliated against is one way to fulfill that responsibility .... There can never be too many taxpayer watchdogs, so I see this letter as an opportunity to foster a mindset that recognizes the value of whistleblowers and the duty these companies have to act honestly when seeking taxpayer dollars. ${ }^{266}$

\section{B. Neither Qui Tam Statutes nor Bounty Programs are not a Substitute for Whistleblower Protection}

The federal government has recently stepped up its efforts to fight fraud in a variety of settings by making it easier for individuals who know of fraud, waste, or abuse of federal funds to receive a substantial financial benefit by coming forward with the information. These efforts include

266. Press Release, Charles Grassley, Charles Grassley Works to Empower Whistleblowers, Protect Tax Dollars (July 1, 2010), available at http://www.grassley.senate.gov/ news/Article.cfm?customel_dataPageID_1502=27347. 
strengthening a very old incentive, qui tam suits, and a newer one focusing on bounties. Both link the whistleblower's recovery directly to the amount recovered by the government. These programs are successful because they directly address the problem for which they were designed: fraud, waste, and abuse against the federal government. The whistleblower provisions in this article, however, are aimed at saving money, they are aimed at saving lives. Courts have supported the government's recent efforts to characterize actions by pharmaceutical companies to hide dangers as false claims because the drugs themselves were subsequently purchased through the Medicare or Veterans Health Administration systems. However, neither the availability of a qui tam suit nor a Bounty program will make it more likely than informant who knows of a danger which does not involve a substantial financial loss to the federal government.

\section{Qui Tam Actions}

In 1863, the United States Congress adopted a venerable English legal doctrine called qui tam in order to allow private citizens to bring lawsuits on the government's behalf in order to recover from individuals and corporations who had defrauded the government by submitting false bills for services. ${ }^{267}$ Under the False Claims Act, ${ }^{268}$ the Federal Government has developed a program through which private citizens are authorized to bring lawsuits when in return for a share of the money recovered. This extension of federal authority is intended to expand the government's resources for recovering funds lost to waste, fraud, or abuse. Although by no means restricted to the area of health law, suits against hospitals, doctors, and other participants in the federal Medicare program are extremely lucrative and the government is quick to publicize large dollar victories. Taxpayers Against Fraud, a nonprofit organization, reports that whistleblowers have helped state and federal governments recover $\$ 3.9$ billion dollars between fiscal years 2002 and $2006{ }^{269}$

267. For an excellent history of the development of the False Claims Act see Eric M. Fraser (Comment), Reducing Fraud Against the Government: Using Foia Disclosures In Qui Tam Litigation, 75 U. CHI. L. REV. 497, 501-504 (2008).

268. The False Claims Act is codified at 31 USC $\$ \S 3729-33(2000)$ and in relevant part states that "A person may bring a civil action for a violation of section 3729 for the person and for the United States Government." 31 U.S.C \& 3730 (2011). Andy Schneider, THE ROLE OF THE FALSE Claims ACT IN COMBATTING MEDICARE AND MEDICAID FRAUd By DRUG MANUFACTURERS: AN UPDATE (2007), available at www.taf.org/schneider07drugreport.pdf.

269. According to the report, If you are still employed by the company you file a qui tam case against, your identity will remain secret so long as your case is under seal with the U.S. Justice Department. In some cases an employer may guess which employee blew the whistle based on the past actions of the relator and/or the types of questions being asked by the government. Harassment or ostricization by management and fellow employees is common 
Qui tam actions are available to those who suspect fraud or wrong doing on the part of pharmaceutical companies if that fraud takes the form of billing the federal government through Medicaid, Medicare, or the Veteran's Health Administration. Writing of Pfizer's \$2.3 billion settlement of allegations that it promoted off-label use of drugs which were then paid for through federal programs, blogger Steve Grossman notes that qui tam whistleblowers brought the wrong-doing to light and stood to gain substantial profit from their share in the recovery. ${ }^{270}$ However, there are dangers to bringing these actions and not all cases of danger to the public result in substantial financial recoveries. While the law protects those bringing these suits, called relators, from retaliation, they often experience retaliation anyway. A study of qui tam actions brought between 1996 to 2005 published in the Annals of Internal Medicine found that despite "a strict prohibition on retaliatory action against whistleblowers" under the statute, "the cases we analyzed frequently included descriptions of the considerable pressures put on whistleblowers and the many unpleasant experiences they faced after helping initiate DOJ enforcement actions."271 For example, according to the authors of the study, a physician who brought an action against his hospital "reported that his hospital employer fired him and then prevented him from informing his patients of his relocation."272 This led the authors to conclude that despite the potential for significant financial gain, "[t]he ongoing viability of the qui tam model depends on the willingness of whistleblowers to come forward.",273

The issue of "willingness to come forward" is an important distinction between those contemplating a qui tam action and the medical researcher with knowledge of harm to a human's health or safety. Research suggests that those bringing qui tam actions do so in order to make money. ${ }^{274}$ The Pfizer case was brought by a drug representative who claimed to be "ap-

in such situations, and the whistleblower may even be fired, demoted, or suspended.

What are False Claims Act Cases?, TAXPAYERS AgAInst Fraud EduCATION Fund, http://www.taf.org/whistle blower.htm (last visited Feb. 12, 2012).

270. Grossman, supra note 202.

271. Aaron S. Kesselheim \& David M. Suddert, Whistleblower-Initiated Enforcement Actions against Health Care Fraud and Abuse in the United States, 1996 to 2005, 149 ANNALS OF INTERNAL MED. 342 (2008) (a study of 379 cases brought by private individuals alleging violations of Medicaid and Medicare laws showing that between 1996 and 2005, these whistleblowers received over $\$ 1$ billion as their share of the $\$ 9.3$ billion recovered by the federal government).

272. Id. at 347 (citing James S. Lubalin and Jennifer L. Matheson, The Fallout: What Happens to Whistleblowers and Those Accused by Exonerated of Scientific Misconduct?, 5 SCI. ENG. ETHICS 229 (1999)).

273. Id.

274. Christina Broderick, Note, Qui Tam Provisions and the Public Interest: An Empirical Analysis, 107 CoLUM. L. REV. 949, 961-63 (2007) (reviewing data showing qui tam relators are motivated by money). 
palled by Pfizer's tactics in selling the pain drug Bextra."275 $\mathrm{He}$ and five other whistleblowers will share a recovery of $\$ 102$ million dollars. However, in the case of a medical researcher or pharmaceutical company employee who seeks to lose her job and perhaps her career, even that amount of money would not be worth the likelihood of having to find another career.

Since this article is concerned with encouraging those with knowledge of a patient's health or safety to come forward, regardless of whether there is a high dollar recovery available, the whistleblower protection provisions of the False Claims Act are no substitute for comprehensive protection. If effective and comprehensive whistleblower protection were available, it may be preferable to qui tam actions and may encourage more people with knowledge to come forward.

Although the qui tam statutes provide protection against retaliation, retaliation is not nearly as much a problem because the kinds of people who bring these actions only do so with the benefit of substantial documentation. Whistleblower statutes, on the other hand, are there to provide incentives when there is no financial gain to anyone.

\section{Federal Whistleblower Laws}

There are at least twenty-one federal statutes that incorporate explicit whistleblower protection for employees of private companies. ${ }^{276}$ These include "protect[ing] employees who report violations of various airline, commercial motor carrier, consumer product, environmental, financial reform, food safety, health care reform, nuclear, pipeline, public transportation agency, railroad, maritime and securities laws," and are overseen by the Occupational Safety \& Health Administration (OSHA) through its office of the Whistleblower Protection Program (OWPP). ${ }^{277}$

The OWPP defines its protection as follows,

The Occupational Safety and Health Act (OSH Act) and a number of other laws protect workers against retaliation for complaining to their employers, unions,

275. BILL BERKROT, Pfizer Whistleblowers Ordeal Reaps Big Rewards, Reuters (SEPT. 2, 2009), http://www.reuters.com/article/2009/09/02/us-pfizer-whistleblower-idUSN021592 920090902.

276. The Whistleblower Program, U.S. DEP'T LABOR, http://www.whistleblowers.gov/ index.html (last visited Feb. 12, 2012).

277. These acts are Section 11(c) of the Occupational Safety and Health Act of 1970 (OSHA); the Surface Transportation Assistance Act of 1982 (STAA); the Asbestos Hazard Emergency Response Act of 1986 (AHERA); the International Safe Container Act of 1977 (ISCA); the Safe Drinking Water Act of 1974 (SDWA); the Federal Water Pollution Control Act of 1972 (FWPCA); the Toxic Substances Control Act of 1976 (TSCA); the Solid Waste Disposal Act of 1976 (SWDA); the Clean Air Act of 1977 (CAA); the Comprehensive Environmental Response, Compensation and Liability Act of 1980 (CERCLA). Id. 
the Occupational Safety and Health Administration (OSHA), or other government agencies about unsafe or unhealthful conditions in the workplace, environmental problems, certain public safety hazards, and certain violations of federal provisions concerning securities fraud, as well as for engaging in other related protected activities. ${ }^{278}$

According to the Act, "[w]histleblowers may not be transferred, denied a raise, have their hours reduced, or be fired or punished in any other way because they have exercised any right afforded to them under one of the laws that protect whistleblowers." 279 However, even if the OWPP could effectively manage the retaliation complaints it receives, it would not provide protection for those who learn of danger to the public's health and safety unless that danger was of the type prohibited by a federal law or regulation. Here again, the fragmentation of human subject research is a substantial barrier to comprehensive whistleblower protection. The question isn't then whether there are federal statutes protecting whistleblowers; it is whether they are effective.

\section{State Whistleblower Laws Do Not Protect Most Medical Researchers}

Most states provide some kind of legal protection to their employees who disclose waste, fraud, or abuse in government. ${ }^{280}$ Thirty-nine states have whistleblower statutes that provide general whistleblower protection to public employees; twenty-three states provide general protection for all employees; and, fourteen states provide specific protection to persons reporting certain environmental misconduct. ${ }^{281}$ The literature describing the flaws of this existing system, usually called a patchwork, is extensive. The failure of the existing statutes comes from their misplaced emphasis on the employment status of the whistleblower rather than the potential danger to the public if the potential whistleblower does not feel safe disclosing what she knows. For example, most whistleblower laws protect only those individuals who have disclosed information exactly in the manner described by the statute. An individual with knowledge of a danger to the public's health or safety may find herself fired because she reported it to her direct supervi-

278. Whistleblower Protections, U.S. DEP'T LABOR, http://www.dol.gov/compliance/ laws/comp-whistleblower.htm (last visited Nov. 15, 2011).

279. Whistleblower Protections, U.S. DEP'T LABOR, http://www.dol.gov/compliance/ laws/comp-whistleblower.htm (last visited Nov. 15, 2011).

280. Robert R. Kuehn, Suppression of Environmental Science, 30 AM. J.L. \& MED. 2004333,356 (2004).

281. Id. 
sor rather than public entity specified by a specific statute. ${ }^{282}$

States vary widely both in the terms of who is defined as a whistleblower and what protections are available to meet the criteria. These statutes protect researchers working at state universities, but the protection offered them is far from complete. In addition, by definition, statutes intended to protect state employees would not be available for researchers at private universities. For example, a physician overseeing a drug trial at the University of California at Berkley will have different protection if he or she reports a dangerous situation involving human protection than one at Stanford University who may well be over-seeing a trial of the same drug.

This lack of consistency is exactly what concerned Justice Souter in Garcetti who wrote, "[T] individuals doing the same sorts of governmental jobs and saying the same sorts of things addressed to civic concerns will get different protection depending on the local, state, or federal jurisdictions that happened to employ them."283

\section{CONCLUSIONS}

Prescription drugs are a firmly entrenched and highly dangerous feature of contemporary U.S. culture. The current system of protecting Americans from the dangers of prescription drugs both while they are being developed and after they are on the market is killing the people the drugs are intended to protect. Although the FDA has the authority to regulate the research process and to monitor drug safety after approval, it has not exercised its power in a way that adequately protects the public's health. Although there are dozens if not hundreds of different statutes and regulatory schemes which attempt to encourage those who know of danger to the public's health or pocketbook to bring the information forward, none of them provide adequate incentive or protection in what has become the highly fragmented and complex process of drug development. Individuals with knowledge might be located out of country or internationally and be employed by a variety of different entities including government agencies, pharmaceutical companies, and private universities.

In light of the many gaps and weaknesses in the current regulatory system, this Article has proposed several ways to protect the public's health by providing those with the most knowledge of the process, individuals involved directly in research and development regardless of whether they are employed by public or private employers, with a method of bringing infor-

282. See Gerard Sinzdak, An Analysis of Current Whistleblower Laws: Defending a More Flexible Approach to Reporting Requirements, 96 CAL. L. REV. 1633, at 1644-50 (presenting four case studies of how "rigid report recipient requirements" frustrate the intent to protect individuals with knowledge of serious dangers).

283. Garcetti v. Ceballos, 547 U.S. 410, 441 (U.S. 2006) (Souter, J., dissenting). 
mation directly to the FDA's attention with protection against retaliation. Primarily this Article proposes that companies seeking the FDA's approval to test or market a new drug in the United States must certify that they have in place a mechanism for those with knowledge to bring information forward to the FDA without fear of retaliation.

Any effort to reform a process that has not previously been subject to comprehensive regulation raises many significant normative and logistical problems. It will be necessary for law and policy makers to consider how protection of the public's health is to be weighed against the interest of research institutions and the pharmaceutical companies, which together develop and profit from the relative lack of regulation over the sale and advertising of prescription drugs in the United States. As the U.S. population ages and becomes even more reliant on the safety and efficacy of prescription drugs, we cannot simply sit back and let the inadequate and ineffective legal system of regulation continue as it has, but rather we must find a way to provide better protection for those who voluntarily agree to test new drugs as well as those who will someday depend on them for survival. 
